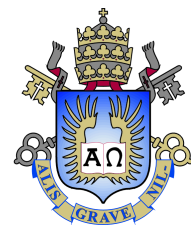

Roberta Beck Tabajara

\title{
Campaign Contributions and Credit: Evidence from Brazil
}

Dissertação de Mestrado

Thesis presented to the Programa de Pós-graduação em Economia da PUC-Rio in partial fulfillment of the requirements for the degree of Mestre em Economia .

Advisor: Prof. Claudio Abramovay Ferraz do Amaral 


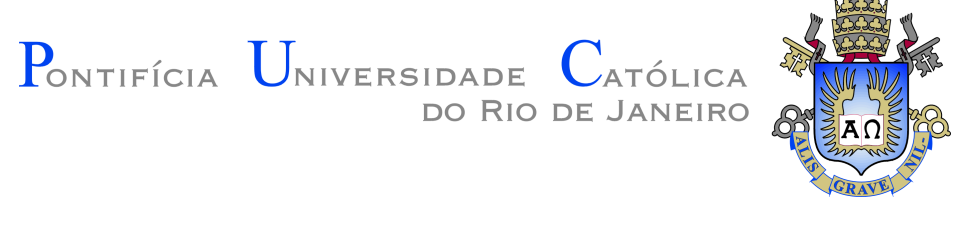

Roberta Beck Tabajara

\section{Campaign Contributions and Credit: Evidence from Brazil}

Thesis presented to the Programa de Pós-graduação em Economia da PUC-Rio in partial fulfillment of the requirements for the degree of Mestre em Economia . Approved by the undersigned Examination Committee.

Prof. Claudio Abramovay Ferraz do Amaral

Advisor

Departamento de Economia - PUC-Rio

Prof. Juliano Junqueira Assunção

Departamento de Economia - PUC-Rio

Prof. Arthur Amorim Bragança

Departamento de Economia - PUC-Rio

Rio de Janeiro, April the 10th, 2019 
All rights reserved.

\section{Roberta Beck Tabajara}

B.A., Economics, Universidade Federal do Rio Grande do Sul (UFRGS), 2017.

Bibliographic data

Tabajara, Roberta Beck

Campaign Contributions and Credit: Evidence from Brazil / Roberta Beck Tabajara; advisor: Claudio Abramovay Ferraz do Amaral. - Rio de janeiro: PUC-Rio, Departamento de Economia , 2019.

v., 51 f: il. color. ; $30 \mathrm{~cm}$

Dissertação (mestrado) - Pontifícia Universidade Católica do Rio de Janeiro, Departamento de Economia .

Inclui bibliografia

1. Economia - Teses. 2. Economia Política - Teses. 3. Contribuições de Campanha. 4. Conexões Políticas. 5. Crédito.

I. Ferraz, Claudio. II. Pontifícia Universidade Católica do Rio de Janeiro. Departamento de Economia . III. Título. 


\section{Acknowledgments}

This dissertation is the final product of two years of much learning as a master's student at the Department of Economics of PUC-Rio. I am very grateful to all the professors and colleagues that were beside me in this journey for providing me with an enriching academic environment. In particular, I thank Prof. Claudio, for guidance in this work and also for all support in those two years. I also thank Prof. Juliano and Arthur Bragança for their helpful insights.

Concluding this step wouldn't be possible without the support from family and friends. I thank my friends from Colégio Anchieta who have always encouraged me. To my friends from UFRGS who helped me figure out economics. To my roommates and master classmates, Cateria and Marcela, with whom I could always share doubts and frustrations. Also to all those with whom I lived happy moments in Rio de Janeiro that made it possible for me to call this city my second home.

I am eternally grateful to my family, my unconditional source of support and love. To my grandmothers who have always been examples of great women. To my sister, Fernanda, the best friend I could have. To my father, the best teacher that life could give me and who taught me the most important things I know. To my mother, for doing absolutely everything for me.

Finally, I thank to all Brazilian taxpayers who once again contributed to the financing of my studies through the Coordenação de Aperfeiçoamento Pessoal de Nível Superior - Brasil (CAPES) - Código de Financiamento 001. Financial support from PUC-Rio is also gratefully acknowledged 


\section{Abstract}

Tabajara, Roberta Beck; Ferraz, Claudio (Advisor). Campaign Contributions and Credit: Evidence from Brazil. Rio de Janeiro, 2019. 51p. Dissertação de mestrado - Departamento de Economia, Pontifícia Universidade Católica do Rio de Janeiro.

In this paper, I study the relationship between allocation of credit and political campaign contribution. In order to achieve this goal, I use loan data on indirect operations from Brazilian development bank (BNDES) at the firm level between 2003 and 2014. Exploring variation for the same firm contributing and not contributing to political campaign and for type of bank, I test if firms that contribute to political campaign at the federal level have preferential access to credit through firm-bank, firm-time and bank-time fixed effect. I find that politically connected firms increase their likelihood of receiving a loan from state-owned banks. On the other hand, they have a lower probability of receiving a loan from private banks. Results for intensive margin show that companies connected with politicians at the federal level receive, on average, greater credit from federal banks. In addition, these companies borrow lower amounts from private banks. This effect is concentrated on the credit line used to fund machine and equipment. Heterogeneous effects of connections with winning and losing candidates vary according to the econometric model I use.

\section{Keywords}

Campaign Contributions Political Connections; Credit 


\section{Resumo}

Tabajara, Roberta Beck; Ferraz, Claudio. Contribuições de campanha e Crédito: Evidência no Brasil. Rio de Janeiro, 2019. 51p. Dissertação de Mestrado - Departamento de Economia , Pontifícia Universidade Católica do Rio de Janeiro.

Nesse artigo, eu estudo a relação de alocação de crédito e contribuições de camapanhas políticas. Para atingir tal objetivo, eu uso dados de emprestimo das opereções indiretas do banco nacional de desenvolvimento economômico e social (BNDES) no nível da firma entre 2003 e 2014. Explorando variação da mesma empresa contribuindo e não contribuindo para campanhas políticas e de tipos de bancos, eu testo se firmas que contribuíram para campanhas políticas no nível federal têm acesso preferencial a credito por meio de efeito fixo de firma-banco, firma-tempo e de banco-tempo. Eu encontro que empresas conectadas politicamente vêem sua probabilidade de receber um empréstimo de bancos federais aumentar. Por outro lado, elas têm uma probabilidade menor de receber de bancos privados. Resultados na margem intensiva indicam que empresas conectadas com políticos no nível federal recebem, em média, contratos de crédito maiores de bancos federais. Além disso, essas empresas tomam emprestado valores menores de bancos privados. Esse efeito é concentrado na linha de crédito usada para financiar máquinas e equipamentos. Efeitos heterogêneos de conexões com candidatos ganhadores e perdedores variam de acordo com o modelo econométrico.

\section{Palavras-chave}

Contribuições de Campanha Conexões Políticas Crédito 


\section{Table of contents}

1 Introduction $\quad 10$

2 Institutional Background $\quad 14$

2.1 Credit to Firms in Brazil 14

2.2 Campaign Contributions in Brazil 18

3 Data and Sample $\quad 21$

$4 \quad$ Empirical Strategy $\quad 26$

5 Results $\quad 28$

5.1 Main Results 28

5.2 Heterogeneous Effects by Electoral Outcome 29

5.3 Heterogeneous Effects by Credit Line 30

$6 \quad$ Impact on Employment $\quad 36$

$\begin{array}{lll}7 & \text { Conclusion } & 39\end{array}$

A Appendix $\quad 45$

A.1 Values by Bank 46

A.2 Additional Descriptive Statistics 49

A.3 Heterogeneous Effect by Electoral Outcome and Credit Line 51 


\section{List of figures}

Figure 2.1 Total Credit to Private Firms by year 16

$\begin{array}{lll}\text { Figure 2.2 Credit Lines by kind of Bank } & 17\end{array}$

$\begin{array}{lll}\text { Figure 2.3 Interest Rate by line and bank } & 17\end{array}$

Figure 2.4 Firms and Individual Contributions by Election 19

Figure 2.5 Number of Firms that contribute by Election 20

Figure 3.1 Contract Amount - Mean 23 


\section{List of tables}

$\begin{array}{lll}\text { Table } 3.1 & \text { Sample } & 23\end{array}$

Table 3.2 Descriptive Statistics - Loan data 24

Table 3.3 Descriptive Statistics on firm' contributions 24

Table 3.4 Firm size - Number of employees 25

Table 5.1 Do Politically Connected firms receive more credit? (Extensive Margin) 32

Table 5.2 Do Politically Connected firms receive more credit? (Intensive Margin) 33

Table 5.3 Heterogeneity by Electoral Outcome 34

Table 5.4 Heterogeneity by Credit Line 35

$\begin{array}{lll}\text { Table } 6.1 & \text { Impact on Employment } & 37\end{array}$

Table 6.2 Elasticity of Credit on Employment 38

Table A.1 Amounts by Bank - $1 \quad 46$

Table A.2 Amounts by Bank - 2 47

Table A.3 Amounts by Bank - 3 48

Table A.4 Descriptive Statistics - Loan data 49

Table A.5 Descriptive Statistics - Number of employees by credit line 50

Table A.6 Descriptive Statistics - Number of employees by kind of candidate $\quad 50$

Table A.7 Heterogeneity by Electoral Outcome and Credit Line 51 5 


\section{Introduction}

The role of corporate money in politics has been the subject of an increasing number of debates. Particularly, previous research has by large found that firms benefit from ties with politicians (Faccio (2006), Ferguson and Voth (2008), Fisman (2001)). Within this scenario, corporate contributions to political races can be a tool to purchase political connections. Although theoretical works predict that politicians exchange their political influence for campaign donations ${ }^{1}$, the empirical evidence is still ambiguous. While Jayachandran (2006) suggests that companies which contribute to politicians enjoy from their access to power, the results presented by Fowler et al. (2019) do not support this idea. Furthermore, as these empirical works concentrate on value market gains, there are some channels to be explored.

Among the benefits a firm can obtain from politicians, preferential access to public credit is relevant for two reasons (Dinc (2005)). Firstly, differently from other government activities, banks operate in the whole economy, providing politicians with more possibilities to channel funds. Secondly, information asymmetry between banks and outsiders makes hiding political interests behind these activities easier. Moreover, it is important to study this kind of preferential treatment because it has severe consequences for the economy. If banks target firms based on political criteria, this can lead to distortions in the financial allocation of resources, affecting productivity and growth (Restuccia and Rogerson (2008), Hsieh and Klenow (2009)).

In this paper I investigate whether firms that contribute to political campaigns receive more credit from government banks in Brazil. The country offers a good opportunity to address this issue. Many politicians and large business owners have been arrested or investigated for purchasing political influence through legal and illegal campaign contributions. This process is known as Car-Wash and it relies on popular support. These investigations concentrate mostly on irregularities on public procurement, but some testimonials suggested that public credit had also been used as an exchange to campaign contributions (Carazza (2018)). After this corruption case came to light, the

${ }^{1}$ See Hillman (1982), Kau et al. (1982) and Snyder (1990). 
Brazilian Supreme Court banned corporate contributions to parties and politicians.

In order to illustrate the relationship between business-owners and the political system in Brazil, one former director of Petrobras, the largest stateowned company, said the following sentence, while giving testimony before the Brazilian electoral court: "Firms do not participate in electoral campaign because of the beauty of politicians' eyes. We think that a company donates $\mathrm{R} \$ 10$ million, $\mathrm{R} \$ 20$ million, to any candidate, and afterwards it will not come after this. No firm does that". This suggests that firms indeed received benefits from contributing to political campaigns in Brazil.

In face of these anecdotal evidences, in this work I test if one of these benefits is preferential access to credit from state-owned banks. I use a unique longitudinal database at the loan contract level, which covers a significant amount of credit operated by private or government-owned bank and funded by the Brazilian Development Bank (BNDES). In order to identify this effect, I explore the variation for the same firm contributing and not contributing to political campaigns. Particularly, I compare the behaviour of private and public banks towards politically connected firms when both types of banks have the same funding cost. This setting allows me to use firm-bank, firm-time and bank-time fixed effect.

My results suggest that politically connected firms receive more credit from state-owned banks. The size of the effect depends on the specification I use. When controlling for bank-firm unobserved heterogeneity constant over time, I find that companies connected with politicians receive on average a credit $13 \%$ larger loans from federal banks. In addition, these companies borrow lower amounts from private banks. When I use firm-time fixed effect, I document that firms that contribute to political campaigns are 7.6 percentage points more likely to receive a loan from state-owned banks. Results for intensive margin indicate that companies connected with politicians receive on average a credit $82 \%$ more credit from federal banks.

In order to test if there is a political channel behind this result, I sort the political variable into connections with winning and losing politicians. Once again, the results for different models do not converge. On the one hand, the estimation with bank-firm fixed effect suggests that the effect is concentrated on connection with politicians who succeed in the election. On the other hand, if I control for shocks at the firm level, I find a positive and significant effect for both types of connections, but the impact for connection with losing candidate is around twice the one for ties with winning candidates.

This work concentrates on three credit lines. Each of them has different 
goals and serves different types of firms. Because of that, I also look at heterogeneous effect by credit line. It seems that the positive effect for political connections comes totally from the credit line destined to fund machine and equipment. Besides that, I estimate a negative effect for credit lines that fund investment projects and a zero effect for credit lines that provide resources to exports.

One of the main goals of the credit studied in this paper is to provide resources to firms that are constrained by credit. Hence, I also study the impact on employment of borrowing money from a BNDES fund by type of bank. I document that credit from both banks has a positive and persistent correlation with future levels of employment. In addition to this, I find a large effect for private banks.

These findings contribute to a extensive literature on the role of politically connected firms. Previous papers have found evidence that these companies are large and have higher profits and market values (Faccio (2006), Ferguson and Voth (2008), Fisman (2001), Acemoglu et al. (2016), Amore and Bennedsen (2013), Jayachandran (2006), Acemoglu et al. (2018), Li et al. (2008) Akcigit et al. (2018)). The definition of political connection is not the same in each of these works. Only Jayachandran (2006) uses campaign contribution as a proxy for connections.

Although all these authors have shown that firms having relations with politicians perform better, the mechanisms behind this have not been fully addressed. Most of the works that attempt to fill this gap concentrate on preferential access to public procurement (Boas et al. (2014), Arvate et al. (2013), Cingano and Pinotti (2012), Baltrunaite (2018), Schoenherr (2019)). Baltrunaite (2018), Boas et al. (2014) and Arvate et al. (2013) also define political connection according to campaign contributions. Baltrunaite (2018) examines how a ban on corporate contributions affects the awarding of procurement contracts to companies that donated in the past. Using data from Brazil, Boas et al. (2014) and Arvate et al. (2013) find that firms specializing in public-works projects can expect a boost in contracts when they donate to a federal-deputy and state-deputy, respectively.

Differently from this literature, I focus on credit as a possible mechanism behind the differential performance of firms connected with politicians. Previous works have found evidence that these companies have preferential treatment in the market credit (Khwaja and Mian (2005), Lazzarini et al. (2015), Claessens et al. (2008), Houston et al. (2014) and Moon and Schoenherr (2018)). Particularly, Claessens et al. (2008) and Lazzarini et al. (2015) investigate this issue in the Brazilian economy using only public information 
of companies listed in the São Paulo Stock Exchange. They also use campaign contributions as a proxy for political connections. Differently from them, I use a database at the contract level and, as a result, I am able to cover a wider variety of firms and I can distinguish credit operated by private and public banks.

My paper is most closely related to Khwaja and Mian (2005). They find that politically connected firms borrow more and have higher default rates. However, I use a different proxy for political connections. While theirs is related to ties within the labour market, mine is based on campaign contributions. Thus, I can also contribute to the literature of why firms participate in political races (Ansolabehere et al. (2003), Fowler et al. (2019), Gordon et al. (2007))

This work is also related to the literature of political influence on state-owned firms. The seminal work of Shleifer and Vishny (1994) explains the inefficiency of state firms by the influence they receive from politicians. Primarily related to public banks, both Dinc (2005) and La Porta et al. (2002) use a panel of countries to support that government ownership of banks politicizes the resource allocation process and reduces efficiency. Cole (2009) and Sapienza (2004) find that public banks are used as a tool of regional favoritism. Within the Brazilian context, Carvalho (2014) finds that firms eligible for a special kind of government bank loan expand employment in politically attractive regions close to the electoral period. Also, Leão et al. (2014) provide evidence that politically aligned cities are favored with more credit from public federal banks. As Khwaja and Mian (2005), I find evidences that state-owned banks concede preferential treatment to politically connected firms.

This paper is organized as follows: besides this introduction, in the next section, I explain the institutional environment where I test the hypothesis of this work. Next, the empirical strategy is presented. Finally, I comment the results and conclude. 


\section{2}

\section{Institutional Background}

\section{1}

\section{Credit to Firms in Brazil}

Brazil has one of the highest interest rates and lowest degree of financial intermediation in the world. As a result, a substantial part of the long-term credit $^{1}$ is managed by the federal government. The loans borrowed by firms are mostly allocated through Brazilian National Development Bank (BNDES). The credit lines funded by this bank are crucial for firms to promote long-term investment and raise their productivity in the Brazilian economy. Thus, firms that have access to these loans may gain comparative advantage vis-à-vis their competitors (Claessens et al. (2008), Carvalho (2014) and Coelho and de Negri (2011)).

BNDES cannot be considered a commercial bank since it does not have agencies where firms can apply for credit. Instead, it operates through two forms: direct and indirect lending. The indirect approach is intermediated by commercial banks, which can be a private, a federal-owned or a bank owned by a regional government. It corresponds to approximately $70 \%$ of total lending of Brazilian development bank. In this case, firms ask these banks for BNDES credit lines, and these financial institutions select the borrowers, and negotiate the loan terms. The development bank only provides the resources for the lending and allows these banks to operate independently. Also, once the loan contact is signed, the commercial bank that operate it are liable for any risk arising from the lending operation. On the other hand, on direct operations, companies apply for loans directly to the government bank, which evaluate their projects and credit risk. Usually, this kind of loan is used to fund large-scale projects such as the development of hydroelectric plants. Thus, I concentrate this study on indirect operations, because it allows me to compare a wider variety of firms.

Figure 2.1 shows the evolution of the value allocated on direct operations and indirect operations by private, regional and federal banks between 2002

\footnotetext{
${ }^{1}$ An operation is considered long-term credit if its grace period and amortization is greater than one year.
} 
and $2014^{2}$. This kind of financing has increased significantly in the past years. This expansion has been the subject of controversial debates related to the political interest behind it $^{3}$.

Besides BNDES, the Brazilian federal government owns four other banks: Banco do Brasil, Caixa Econômica Federal, Banco do Nordeste and Banco da Amazônia. They all operate the credit lines funded by the development bank. Particularly, Banco do Brasil is the second commercial bank which participates more on indirect operations. As well as BNDES, these four banks are managed by the executive cabinet, and the President appoints the board of directors of each bank. Also, the congress is one of the institutions responsible for inspecting the activities of these public companies. For these reasons, I concentrate this study on campaign contribution to candidates who run for presidency and the congress.

In this paper, I focus on the major credit lines in indirect operations. They are BNDES Finame, BNDES Automático and BNDES Exim Pré-Embarque. The first one is used to fund machine and equipment, such as the purchase of a truck. Firms hire BNDES Automático in order to finance investment projects, such as modernization of fixed assets or research projects. The last line is used to fund exports.

Figure 2.2 shows the composition of credit portfolio of private and federal banks. The amount allocated to Finame is the largest in both banks. However, proportionally, BNDES Automático and BNDES Exim Pré-Embarque have a higher importance in the federal bank's portfolio than they have in the private banks' portfolio.

Figure 2.3 shows the mean of interest rate by type of bank and credit line. The interest rate of BNDES Exim Pré-Embarque is not available. For loans operated by federal banks, the mean interest rate is $4.62 \%$ for funding machine and equipment and $6.04 \%$ for investment projects. The loans in private banks cost a slightly more in both lines. It is worth pointing out that the mean annual inflation rate in the period was $5.91 \%{ }^{4}$. This shows that these interest rates are low within the context of the Brazilian economy.

${ }^{2}$ In Appendix A, I present the amounts allocated to each bank.

${ }^{3}$ In 2015, the National Congress opened a Comissão Parlamentar de Inquérito (CPI) to investigate alleged irregularities between 2003 and 2015.

${ }^{4}$ Mean annual inflation rate between 2003 and 2014 measured by IPCA 
Figure 2.1: Total Credit to Private Firms by year

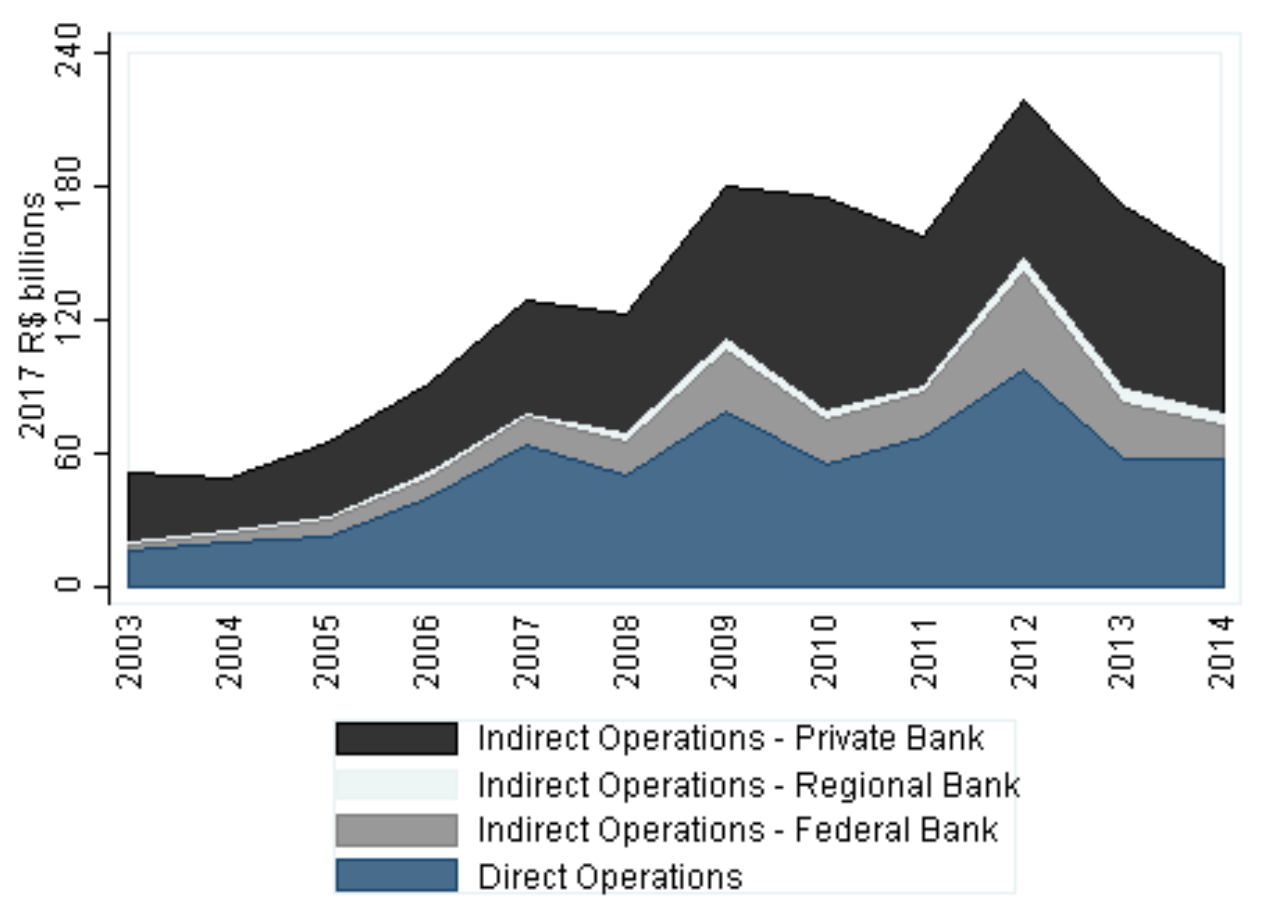

Note: Total credit to private firms from BNDES by year and kind of operation. Amounts are in billions R $\$ 2017$. 
Figure 2.2: Credit Lines by kind of Bank

Federal Banks

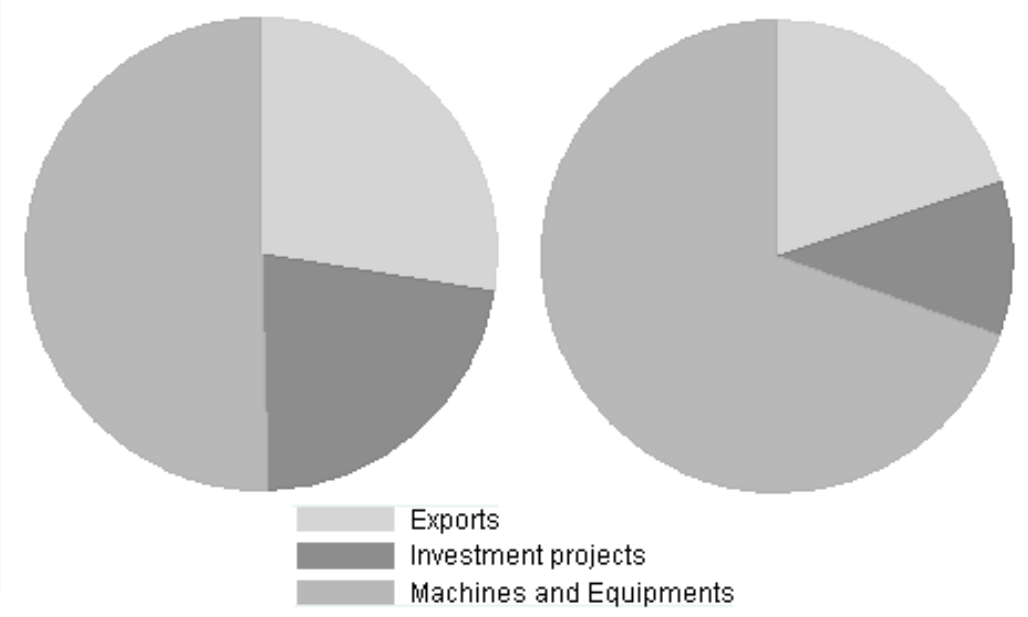

Note: This figure shows the allocation of resources in each credit line by type of banks. The total amount offered in the period by federal banks is $\mathrm{R} \$ 151,287,283,712$ in 2017 values. Finame line represents $50 \%$ of this amount; Automático line represents $27 \%$ of this amount, and Exim line represents $22 \%$ of this amount. The total amount offered in the period by private banks is $\mathrm{R} \$ 600,004,493,312$ in 2017 values. Finame line represents $60 \%$ of this amount; Automático line represents $20 \%$ of this amount, and Exim line represents $10 \%$ of this amount.

Figure 2.3: Interest Rate by line and bank

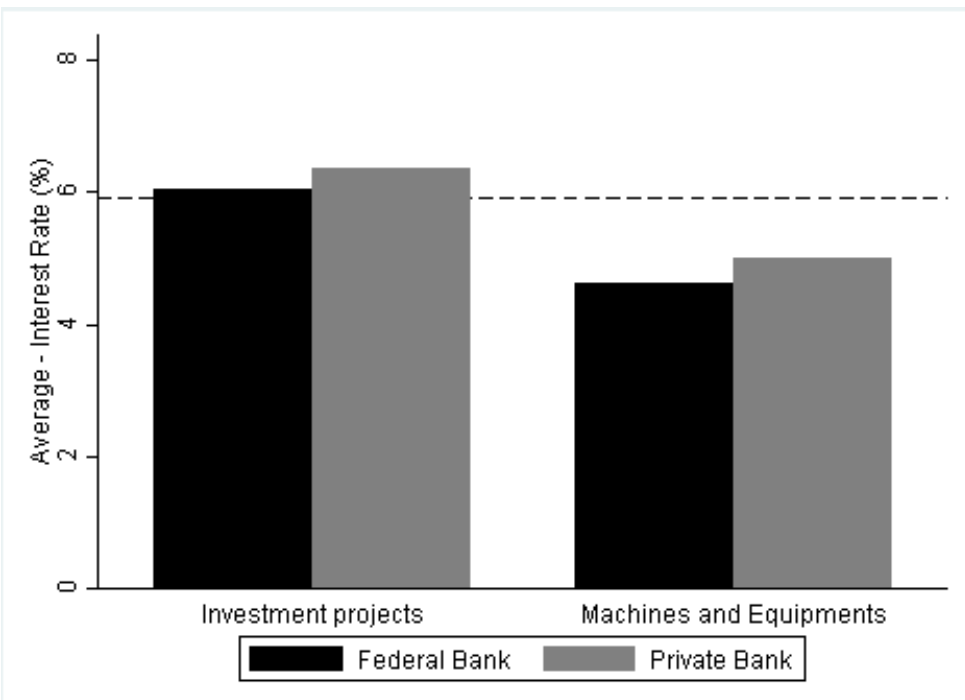

Note: This figure shows the mean interest rate by credit line and type of bank. The dash line is the mean annual inflation rate between 2003 and 2014 measured by IPCA. 


\section{2}

\section{Campaign Contributions in Brazil}

Brazil is a federal country with three levels of government: federal, regional and local. There are 26 states and one federal district in the regional dimension and 5,567 municipalities in the local one. Each level has its executive and legislative power. The national and regional elections for executive and legislative positions occur together every four years, and so are the municipality elections. However, the latter occur mid-term in relation to the national elections.

The legislative power in the national level is made up of two houses. The Lower House is called Chamber of Deputies and comprises 513 members elected through a state-proportional system. The Upper House is known as Federal Senate and is made up by 81 politicians elected by majority vote. Moreover, the country has more than 30 parties and at least four of them play an important role in the national scenario.

The activities of these parties are funded by different sources. Besides public funding and individual contributions, firms were allowed to donate money to election races between 1994 and 2014. The cap on firm's contribution was $2 \%$ of their gross annual revenue in the year before the election. Contributions can be directed to the candidate or party election committee in the federal, regional and local levels. Since 2010, contributions can also be made to the party directory. The parties must submit an overview of their campaign revenues and expenses to the Brazilian Electoral Court. Candidates and parties are subject to penalties if they do not report their campaigns' cash flow correctly.

Most citizens do not identify themselves with a single party, and it is not uncommon for politicians to switch party affiliations. This weak party organization implies that publicity in elections are likely to influence electoral outcomes. For these reasons, candidates have a strong demand for contributions. The amounts available from public funding are small comparing with the amounts the candidates can raise from the private sector. Especially in legislative positions, this point is still more relevant, since parties usually allocate public funding to the executive races. Also, proportional elections encourage competition among candidates within the same party. Politicians who run for Chamber of Deputies usually cannot rely on party organizations to get money for their campaigns. As a result, they have an even greater need for private donations (Boas et al. (2014) and Claessens et al. (2008)) .

Another point that must be taken into account in the context of this paper is the fact that elected officials have a long-term career in Brazil. Even 
though the incumbency rate is lower than in US, they usually run for different positions in each elections (Boas et al. (2014) and Samuels (2003)). Thus, there are repeating interactions between candidates and contributing firms. This leads to a bargain between politician and donor, in which each one may impose sanctions to the other if they do not achieve their goal. This mechanism supports the idea that firms may benefit from ties with politicians. Otherwise, they would penalize them by not contributing.

In Figure 2.4, I plot the amount contributed by firms and individuals in the 2002, 2006 and 2010 National Elections. The amount raised through corporate donors is much greater than the amount contributed by individuals. The point that stands out is the significant rise in the amount of money from firms between 2002 and 2010. This shows that the willingness of firms to participate in electoral races increased in these years. Another fact that also supports this idea is shown in Figure 2.5. It plots the evolution in the number of firms contributing to campaigns for federal offices. There is also a rise in the number of firms between each election. Therefore, these two figures show that the role of corporate money in Brazilian election has growth.

Figure 2.4: Firms and Individual Contributions by Election

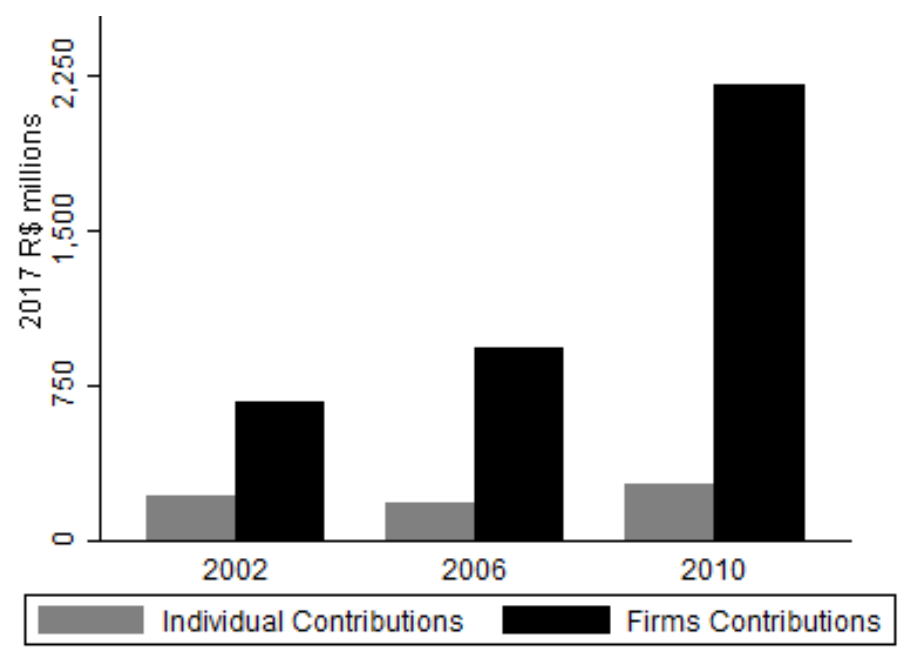

Note: Firms and Individual Contributions received by all candidates to congress and presidency by election in millions $\mathrm{R} \$ 2017$. 
Figure 2.5: Number of Firms that contribute by Election

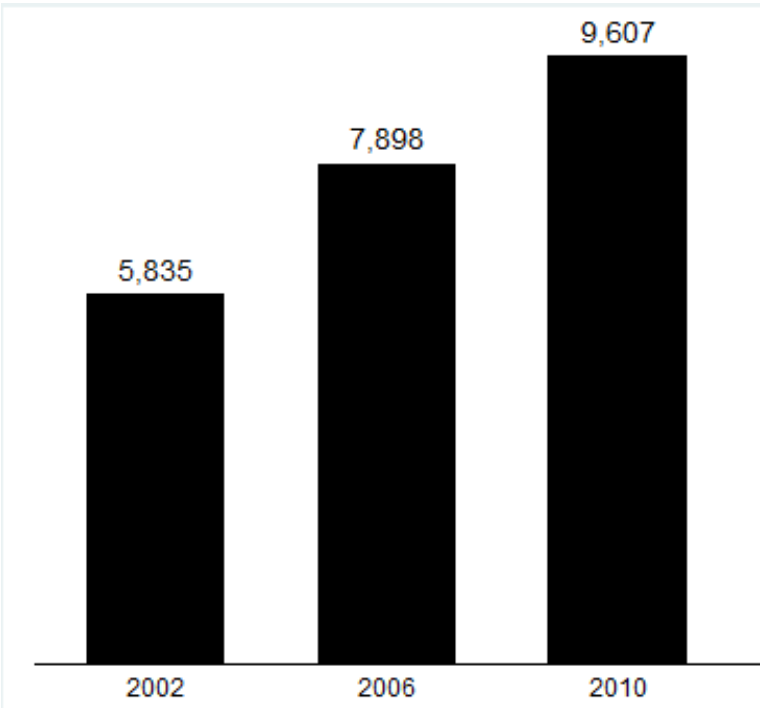

Note: Number of firms that contribute to candidates, committees and parties at the federal level. 


\section{3 \\ Data and Sample}

I rely on three sources of data. I match these three database by using the first eight digits of Cadastro Nacional de Pessoas Juridicas (CNPJ), which is the tax identifier of the firm with the Brazilian authorities.

The loan data covers more than 3 million credit operations. It contains detailed information on each loan, such as date, amount, interest rate, grace and amortization period, and state and municipality where the financed project will be implemented. Since I focus my attention to indirect operations, I can also identify the bank which operates each loan. I exclude the ones contracted by public organizations, because only private firms can participate in political campaigns. I also exclude loans operated by banks owned by a regional government since I am interested in the political behaviour of candidates who run for federal positions.

I use publicly available electoral records for 2002, 2006 and 2010 general elections from the Superior Electoral Court (TSE). TSE provides information on election results for candidates to presidency, Chamber of Deputies and Federal Senate. They also provide information on all revenues and expenses of each candidate, committees and party directory in each election. Regarding revenues, there is information on the name of the donor, its official register number and the amount donated. I exclude the contributions from firms of the financial sector because this sector does not appear on the BNDES database.

RAIS is an administrative matched employer-employee dataset managed by the Ministry of Labour (Minisério do Trabalho e Emprego), which provides information on the universe of workers in both public and private sectors. From this data, I use information at the firm level regarding their number of employees, year of opening and closing and economic sector.

My dataset includes all firms that appear at least once in the BNDES database or TSE database. As shown in Table 3.1, from the loan database, I have information on credit operations of 285,988 companies. More than half borrowed only from private banks in the period, and around 75 thousand firms use only federal banks to have access to the credit lines covered in this paper. Almost 40 thousand companies use both types of banks. From TSE database, I identify 19,000 firms that contribute at least once to candidates, committees 
or party's directory at the federal level. I am able to find 6,237 firms in both BNDES and TSE database. Thus, I use information about 298,751 firms in the remainder of this work.

Figure 3.1 shows the mean contract amount by type of bank and firm political status. Regarding loans operated by federal banks, the mean loan amount is about $\mathrm{R} \$ 1,565$ thousand for firms that contributed to political campaign and about $\mathrm{R} \$ 420$ thousand for firms that did not participate in any electoral races in the period. This difference also appears in loans operated by private banks, however, it is smaller. On average, the amount of credit operation for these firms which have relations with politicians is $\mathrm{R} \$ 1,228$ thousand and for those which do not have is $\mathrm{R} \$ 398$ thousand.

More descriptive statistics on the loan data are depicted in Table 3.2 . The mean total annual loan is $\mathrm{R} \$ 3,379$ thousand for connected firms borrowing from federal banks and $\mathrm{R} \$ 4,976$ thousand for connected firms borrowing from private banks. For not connected companies, the mean total annual loan is $\mathrm{R} \$$ 510 thousand in federal banks and $\mathrm{R} \$ 471$ thousand in private banks.

An overview of the participation of the firms in the elections is available in Table 3.3. It shows that most companies contribute in only one election in the period. Conditional on having participated in the political race, on average, they made 1.6 contributions and they established ties with 1.3 candidates. However, it is worth noting that there is a large variance between firms. For example, while many firms contributed to one party, other donated to 17 parties in the same election.

Descriptive statistics on the size of firms included in the analysis are available on Table $3.4^{2}$. I use the number of employees as a proxy for the size of the company in the remainder of this paper. On average, connected firms are larger than not connected ones. Regarding firms from the BNDES database, the ones which borrow from both types of banks in the period have, on average, around twice the number of employees of the ones that borrow only from federal or private banks. Still, on average, firms that sign credit contracts with federal banks have more employees. Concerning firms connected with politicians, the ones that contribute to winning candidates have, on average, 354 workers. The ones connected with losing politicians have, on average, 153 employees.

\footnotetext{
${ }^{1}$ In Appendix B, I present descriptive statistics by credit line

${ }^{2}$ In Appendix B, I present descriptive statistics about the number of employees by credit line and position
} 
Figure 3.1: Contract Amount - Mean

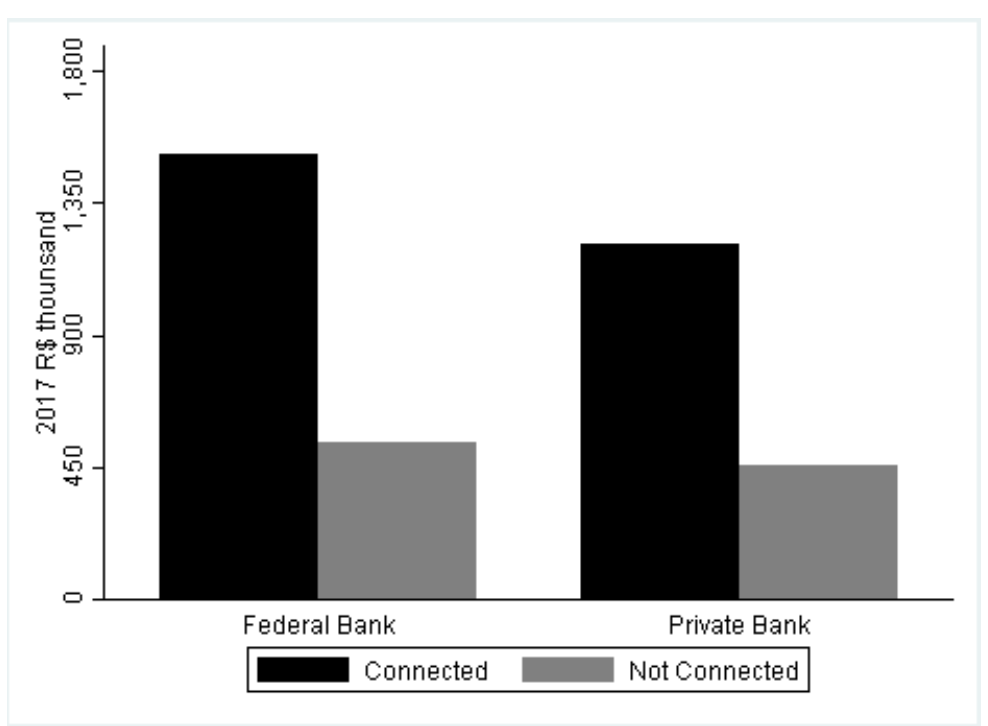

Note: Mean Contract Amount by type of bank and firm political status. Amounts are in 1,000 R $\$ 2017$. A firm is considered connected if it contributes at least once for candidates, committees and party directory.

Table 3.1: Sample

\begin{tabular}{lr}
\hline \hline Number of firms from BNDES database & 285,988 \\
Borrow only from federal banks & 74,838 \\
borrow only from private banks & 171,827 \\
Borrow from both types & 39,323 \\
& \\
Number of firms from TSE database & 19,000 \\
& \\
Number of matching firms & 6,237 \\
\hline
\end{tabular}


Table 3.2: Descriptive Statistics - Loan data

\begin{tabular}{lcccc}
\hline \hline & $\mathrm{N}$ & mean & median & sd \\
\cline { 2 - 5 } Individual loan (In R\$ 1,000) & & & & \\
Federal Banks & & & & \\
Connected Firms & 16,421 & $1,565.70$ & 330.00 & $10,555.72$ \\
Not Connected Firms & 179,649 & 420.68 & 138.40 & $3,329.31$ \\
& & & & \\
Private Banks & & & & \\
Connected Firms & 80,662 & $1,228.52$ & 291.55 & $6,383.69$ \\
Not Connected Firms & 737,591 & 398.30 & 170.55 & $2,847.80$ \\
& & & & \\
Total Annual Loan (In R\$ 1,000) & & & & \\
Federal Banks & & & & \\
Connected Firms & 7,641 & $3,379.78$ & 651.00 & $18,760.14$ \\
Not Connected Firms & 148,834 & 510.05 & 147.80 & $5,141.16$ \\
& & & & \\
Private Banks & & & & \\
Connected Firms & 20,073 & $4,976.36$ & 732.00 & $22,879.29$ \\
Not Connected Firms & 399,235 & 741.12 & 203.00 & $6,296.71$ \\
\hline \hline
\end{tabular}

Note: This table shows descriptive statistics on loan data. A firm is considered connected if it contributes at least once for candidates, committees and party directory.

Table 3.3: Descriptive Statistics on firm' contributions

\begin{tabular}{lccccc}
\hline \hline & $\mathrm{N}$ & mean & sd & min & $\max$ \\
\cline { 2 - 6 } & & & & & \\
Number of elections & 19,000 & 1.146 & 0.416 & 1 & 3 \\
Number of contributions & 21,768 & 1.648 & 3.564 & 1 & 165 \\
Number of candidates & 21,768 & 1.375 & 2.818 & 0 & 140 \\
Number of Presidency Candidates & 21,768 & 0.040 & 0.219 & 0 & 4 \\
Number of Upper House Candidates & 21,768 & 0.104 & 0.373 & 0 & 11 \\
Number of Lower House Candidates & 21,768 & 1.085 & 2.096 & 0 & 96 \\
Number of Winning Candidates & 21,768 & 0.651 & 1.509 & 0 & 87 \\
Number of Losing Candidates & 21,768 & 0.509 & 0.994 & 0 & 64 \\
Number of Parties & 21,768 & 1.332 & 1.111 & 1 & 17 \\
\hline \hline
\end{tabular}

Note: This table shows descriptive statistics on firms' contributions. In the first row, the observation level is the firm, conditional on the firm having participated in at least one election. In the remaining rows, the observation level is firm-election, conditional on the firm having participated in the election. 
Table 3.4: Firm size - Number of employees

\begin{tabular}{lcccc}
\hline \hline & $\mathrm{N}$ & mean & median & sd \\
\cline { 2 - 5 } & & & & \\
Whole sample & $2,932,124$ & 44.67 & 5 & 503.40 \\
Connected & 209,357 & 237.97 & 14 & $1,632.96$ \\
Not Connected & $2,722,767$ & 29.80 & 5 & 254.50 \\
& & & & \\
Firms from BNDES database & $2,792,141$ & 41.23 & 5 & 405.09 \\
& & & & \\
Firms that borrow from federal banks & $1,135,989$ & 53.06 & 6 & 489.21 \\
Firms that borrow from private banks & $2,066,335$ & 49.55 & 5 & 464.24 \\
Firms that borrow from both & 410,183 & 115.91 & 13 & 791.59 \\
& & & & \\
Firms from TSE database & & & & \\
& 209,357 & 237.97 & 14 & $1,632.96$ \\
Connected with candidates & & & & \\
Winning & 193,639 & 243.43 & 14 & $1,668.95$ \\
Losing & 108,088 & 354.03 & 24 & $2,167.61$ \\
\hline \hline
\end{tabular}

Note: This table shows descriptive statistics on number of employees. The observation level is firm-year. A firm is considered connected if it contributes at least once for candidates, committees and party directory. 


\section{4}

\section{Empirical Strategy}

This section describes the empirical strategy to assess the presence of a better access to public credit from politically connected firms. As Jayachandran (2006), Baltrunaite (2018) and Titl and Geys (2019), I use campaign contribution as a proxy for political connections. Since the majority of companies does not contribute in all elections studied in this paper, I am able to use firm fixed effect in the estimation to control for observed and unobserved firms characteristics that are constant over time. Hence, I can explore the variation of status of politically connected within firm in order to identify the effect of contributing to electoral races on receiving a loan from BNDES fund ${ }^{1}$. Assuming a linear model, the access to public credit could be represented as:

$$
Y_{i t}=\alpha_{t}+\alpha_{i}+\beta_{1} \text { Political }_{i t}+\beta_{2} X_{i t}+\epsilon_{i t}
$$

where $Y_{i t}$ is a measure of access to public credit of firm $i$ at time $t$, Political $_{i t}$ is an indicator variable that equals one if the company has contributed to the previous election, $\alpha_{i}$ is firm fixed effect, $\alpha_{t}$ is bank-time fixed effect and $X_{i t}$ are firms' characteristics that vary over time . The parameter $\beta_{1}$ measures the impact of being politically connected on loan variables from state-owned banks. The assumption behind this model is that, conditional on firm unobserved heterogeneity constant over time, firms' shocks that affect credit decisions do not correlate with political status. This assumption may not hold if connected firms benefit from policies implemented by politicians with whom they are connected. If this happens, they might be able to increase investment and apply for more credit.

One feature of the institutional setting in this paper generates variation from the type of lenders. Since loans from BNDES are operated by different banks, I can explore the variation from the nature of these institutions. I consider a government bank if the bank is owned by the federal government and a private lender, otherwise. Thus, loans operated by Banco do Brasil, Caixa Econômica Federal, Banco do Nordeste and Banco da Amazônia can be identified in the data as provided by a public bank. Using two observation, public and private credit, for each firm in each period, allows me to use bank-

${ }^{1}$ For similar approach, see Khwaja and Mian (2005), Cingano and Pinotti (2012), Akcigit et al. (2018), Titl and Geys (2019), Moon and Schoenherr (2018). 
time, bank-firm and firm-time fixed effects. However, as I have almost 300 thousand firms in my sample, I am not able to saturate this estimation with these three types of fixed effects because of the lack of computer resources. Thus, I can estimate the following two equations:

$$
\begin{gathered}
Y_{i j t}=\alpha_{j t}+\alpha_{i j}+\beta_{1} \text { Political }_{i t}+\beta_{2} \text { Political }_{i t} * G O V_{j}+v_{i j t}+\epsilon_{i j t} \\
Y_{i j t}=\alpha_{j t}+\alpha_{i t}+\beta_{3} \text { Political }_{i t} * G O V_{j}+v_{i j t}+\epsilon_{i j t}
\end{gathered}
$$

where $Y_{i j t}$ is a measure of access to credit of firm $i$ over bank $j$ at time $t$, Political $_{i t}$ is an indicator variable that equals one if the company has contributed to the previous election, $G O V_{j}$ is an indicator variable that equals one if $j$ is a public bank. $\alpha_{j t}$ is bank-time fixed effect, $\alpha_{j i}$ is bank-firm fixed effect and $\alpha_{i t}$ is firm-time fixed effect. $v_{i j t}$ are unobserved peculiarities of the relationship bank-firm that vary over time, and $\epsilon_{i j t}$ is an error term.

In equation 4-2, the bank-firm fixed effect enables me to ask whether the same firm obtains additional lending preference from a government relative to private bank, when it contributes to political campaigns. This fixed effect imply that this change is for the same pair ${ }^{2}$. In equation 4-3, the firm-time fixed effect controls for all observed and unobserved characteristics of the firms. In both equations, bank-time fixed effect controls for any time-series changes in the volume of lending for a given bank. The identification strategy relies on the assumption that unobservables $\left(v_{i j t}\right)$ are not correlate with the decision of participating of political campaigns.

Since the status of politically connected firms does not change within the political cycle, I collapse the time dimension of the panel to four years, as suggested by Bertrand et al. (2004). Thus, I have three periods of time (2002-2006, 2007-2010 and 2011-2014).

\footnotetext{
${ }^{2}$ Khwaja and Mian (2005) also perform a estimation using bank-firm fixed effect
} 


\section{Results}

\section{1 \\ Main Results}

I estimate the equations explained above in both the intensive and the extensive margins. In the extensive margin, the dependent variable is a dummy that equals one if the firm receives a loan from the bank. In the intensive margin, I use the log of the sum of the amounts of the loans in the period plus one as the dependent variable.

In this section, a firm is considered as politically connected if it contributes to candidates, committees and directories at the federal level. In subsequent specifications, I present the results using other measurements of connections.

The results from estimating equation 4-2 and 4-3 are provided in Table 5.1 for extensive margin. The estimation in column (1) shows that politically connected firms have a 7.68 percentage points greater probability of receiving a loan from a government bank than the unconnected firms. On the other hand, these companies are 5.93 percentage point less likely to obtain credit with private banks. Adding time-fixed effect and controlling for the number of employees almost does not change this result. In Column 4, I control for bank shocks and I continue to observe a positive and significant impact of government banks. Particularly, in Column (5), I add bank-firm fixed effect to the model. The point estimate decreases, but it remains statistically significant. In Column (6), I control together for both bank and firm heterogeneity that varies over time together. It suggests that firms that participate on electoral races enjoy a 7.7 percentage points greater probability of receiving a loan from a government bank than the unconnected firms.

The results for intensive margin are in Table 5.2. Column (1) gives the result using only firm and bank fixed effect. It shows that being connected with politicians causes, on average, an increase of $70 \%$ on the amount of credit from government banks. On the other hand, it has a negative impact on loans from private banks. This result is robust to using as a control time fixed effect, the number of employees, bank and firm shocks (Columns 2, 34,5 and 8). 
However, when I add bank-firm fixed effect, the point estimate decreases. If this specification is correct, it suggests that firms that contribute to political campaigns receive on average a credit $13 \%$ larger loans from federal banks, but they borrow lower amounts from private banks.

These results document that politically connected firms have preferential access to credit from government banks. Although I find a positive and significant effect in all specifications, the size of the effect has a significant variation between the two models (equations 4-2 and 4-3). One possible explanation for this is that connected firms are more willing to interact with public institutions. These type of firms may prefer to ask for credit in a government bank, in addition to finding worth to contribute to political campaigns. This is not accounted for in the model without bank-firm fixed effect, which may lead to a biased result.

\section{2}

\section{Heterogeneous Effects by Electoral Outcome}

Overall, the results suggest that firms connected to politicians at the federal level have preferential access to loans from banks owned by the federal government. If these evidences reveal a political channel, one can expect that firms connected with stronger politicians obtain even greater access to credit from government banks. Thus, in this section I explore variation from the political strength of candidates to whom firms contribute.

Up to this point, I define as being politically connected a firm that contributes to candidates, committees and party's directory. I also consider as being connected with politicians even if it donates only to losing candidates. Hence, the previous estimation can be an average of a heterogeneous effect for connection with candidates who succeed in the election and politicians who do not. As a result, I want to test if the effect of being connected to a politician varies according to the results the politician obtains in the election. If banks concede preferential treatment to firms that participate on electoral races, and this is caused by the existence of a political channel, I expect that firms connected with losing politician will not receive the same treatment.

In order to do that, I cross out of the sample the firms that contribute only to committees and party's directory since I cannot link these firms to an electoral outcome. I want to identify the effect of being an allied firm of a winning politician vis-à-vis a losing one, so I sort the measurement of connections according to the electoral result of the politician to whom the firm contributes. I consider a firm as politically connected $*$ win if it contributes to at least one elected candidate at the federal level. Then, I contrast this last 
measurement with another one related to firms that donate only to non-elected candidates at the federal level. These two variables are mutually exclusive. In this specification, I present the results using only the more saturated models. Results are displayed in Table 5.3.

Once again, the models saturated with dummies of bank-firm effect estimate smaller effects than the one that controls for firm heterogeneity that varies over time in both margins. In addition to this, the estimates of the heterogeneous effect diverges in each model. On the one hand, in column (1) and (3) I estimate that firms connected with winners enjoy an increase of 1.15 percentage points on its likelihood of receiving money from government banks and they also have access to credit contracts $13 \%$ larger from these banks. In addition to this, I cannot reject the hypothesis that the effect for losing candidates is equal to zero. On the other hand, results in column (2) and (4) suggest the opposite. Controlling for firm shocks, my results indicate that companies that contribute only to candidates who do not achieve a position expect a greater increase on the probability of borrowing from federal banks. The results in intensive margin suggest that the effect for connections with losing politicians is twice larger than the one for ties with winning candidates.

In sum, these results reinforce that the hypothesis that equation 4-2 estimates the effect of contributing to political campaign on credit without bias for mainly two reasons. Firstly, using bank-firm fixed effect, as expected, I find a positive and significant effect for connections with winners and a zero effect for ties with losers. Secondly, using the alternative model, I find a greater effect to companies linked only with losing politicians. A political channel of this preferential treatment would reveal the opposite.

\section{3}

\section{Heterogeneous Effects by Credit Line}

I include in this work the three most important credit lines from BNDES Indirect Operations. Each of these lines have different objectives and, consequently, serves a wider variety of firms. To illustrate that, the mean of the number of employees of firms that contract Exim is 20 times larger than companies that use Finame (Table A.5). It is possible that politicians concentrate theirs interests in specific lines. Due to this, in this section I test in this section if there is heterogeneous effect by credit line.

In order to do that, I add one more dimension to my panel. Now each firm in each period has 6 observations: three lines (Finame, Automático and Exim) for each kind of bank (Private Bank and Federal Bank). This allows me to use bank-firm-line fixed effect and bank-time-line fixed effect, besides 
firm-time fixed effect. As explained, I am not able to use these three sets of dummies together. Thus, I estimate these two equations:

$$
Y_{i j k t}=\alpha_{j k t}+\alpha_{i k j}+\beta_{1} \text { Political }_{i t} * \sum_{k=1}^{3} C L_{k}+\beta_{2} \text { Political }_{i t} * G O V_{j} * \sum_{k=1}^{3} C L_{k}+v_{i j k t}+\epsilon_{i j k t}
$$

$$
Y_{i j k t}=\alpha_{j k t}+\alpha_{i t}+\beta_{3} \text { Political }_{i t} * G O V_{j} * \sum_{k=1}^{3} C L_{k}+v_{i j k t}+\epsilon_{i j k t}
$$

where $Y_{i j k t}$ is a measurement of access to credit of firm $i$ over bank $j$ and line $k$ at time $t$, Political $_{i t}$ is an indicator variable that equals one if the firm has contributed to the previous election, $G O V_{j}$ is an indicator variable that equals one if $j$ is a public bank. To simplify, I assign a number to each line, so $C L_{k}$ is a dummy related to each line. $\alpha_{j k t}$ is bank-line-time fixed effect, $\alpha_{j k i}$ is bank-line-firm fixed effect and $\alpha_{i t}$ is firm-time fixed effect. $v_{i j k t}$ are unobserved peculiarities of the triple bank-firm-line that vary over time, and $\epsilon_{i j k t}$ is an error term.

The results are shown in Table 5.4. I present the coefficients of the most saturated regressions. In column 1 and 2, I use a dummy as dependent variable, while in Column 3 and 4 I use the log of the value plus one. It seems that the positive effect is mostly concentrated on Finame Line, regardless of the specification. I also find a negative effect for Automático Line and an effect of almost zero for Exim Line. In the Appendix, I present these specifications sorting the connection into winning and losing and I find similar results.

Finame is the credit line used to fund machine and equipment. This line serves both large and small companies. As shown in Figure 2.2, it concentrates the greatest amount of resources and it has the highest number of contracts in the period studied in this paper. As a result, this kind of credit operation may provide politicians with more possibilities to channel funds. 
Table 5.1: Do Politically Connected firms receive more credit? (Extensive Margin)

\begin{tabular}{|c|c|c|c|c|c|c|c|c|}
\hline & $\begin{array}{c}(1) \\
\text { dummy }\end{array}$ & $\begin{array}{c}(2) \\
\text { dummy }\end{array}$ & $\begin{array}{c}(3) \\
\text { dummy }\end{array}$ & $\begin{array}{c}(4) \\
\text { dummy }\end{array}$ & $\begin{array}{c}(5) \\
\text { dummy }\end{array}$ & $\begin{array}{c}(6) \\
\text { dummy }\end{array}$ & $\begin{array}{c}\text { (7) } \\
\text { dummy }\end{array}$ & $\begin{array}{c}(8) \\
\text { dummy }\end{array}$ \\
\hline Politically Connected & $\begin{array}{c}-0.0328^{* * *} \\
(0.00273)\end{array}$ & $\begin{array}{c}-0.0549^{* * *} \\
(0.00281)\end{array}$ & $\begin{array}{c}-0.0807^{* * *} \\
(0.00273)\end{array}$ & $\begin{array}{c}-0.0851^{* * *} \\
(0.00277)\end{array}$ & & $\begin{array}{c}-0.0446^{* * *} \\
(0.00308)\end{array}$ & $\begin{array}{c}-0.0522^{* * *} \\
(0.00315)\end{array}$ & \\
\hline $\begin{array}{l}\text { Politically Connected } \\
{ }^{*} \text { Government Bank }\end{array}$ & $\begin{array}{c}0.0680^{* * *} \\
(0.00327)\end{array}$ & $\begin{array}{c}0.0680^{* * *} \\
(0.00327)\end{array}$ & $\begin{array}{c}0.0680^{* * *} \\
(0.00327)\end{array}$ & $\begin{array}{l}0.0768^{* * *} \\
(0.00331)\end{array}$ & $\begin{array}{l}0.0680^{* * *} \\
(0.00422)\end{array}$ & $\begin{array}{l}-0.00418 \\
(0.00356)\end{array}$ & $\begin{array}{l}0.0109^{* * *} \\
(0.00364)\end{array}$ & $\begin{array}{r}0.0768^{* * *} \\
(0.00427)\end{array}$ \\
\hline Firm Size & & & $\begin{array}{c}0.108^{* * *} \\
(0.000569)\end{array}$ & $\begin{array}{c}0.108^{* * *} \\
(0.000569)\end{array}$ & & $\begin{array}{c}0.108^{* * *} \\
(0.000637)\end{array}$ & $\begin{array}{c}0.108^{* * *} \\
(0.000637)\end{array}$ & \\
\hline Bank FE & $\mathrm{Y}$ & $\mathrm{Y}$ & $\mathrm{Y}$ & $\mathrm{N}$ & $\mathrm{Y}$ & $\mathrm{N}$ & $\mathrm{N}$ & $\mathrm{N}$ \\
\hline Time FE & $\mathrm{N}$ & $\mathrm{Y}$ & $\mathrm{Y}$ & $\mathrm{N}$ & $\mathrm{N}$ & $\mathrm{Y}$ & $\mathrm{N}$ & $\mathrm{N}$ \\
\hline Firm FE & $\mathrm{Y}$ & $\mathrm{Y}$ & $\mathrm{Y}$ & $\mathrm{Y}$ & $\mathrm{N}$ & $\mathrm{N}$ & $\mathrm{N}$ & $\mathrm{N}$ \\
\hline Bank-Time FE & $\mathrm{N}$ & $\mathrm{N}$ & $\mathrm{N}$ & $\mathrm{Y}$ & $\mathrm{N}$ & $\mathrm{N}$ & $\mathrm{Y}$ & $\mathrm{Y}$ \\
\hline Bank-Firm FE & $\mathrm{N}$ & $\mathrm{N}$ & $\mathrm{N}$ & $\mathrm{N}$ & $\mathrm{N}$ & $\mathrm{Y}$ & $\mathrm{Y}$ & $\mathrm{N}$ \\
\hline Firm-Time FE & $\mathrm{N}$ & $\mathrm{N}$ & $\mathrm{N}$ & $\mathrm{N}$ & $\mathrm{Y}$ & $\mathrm{N}$ & $\mathrm{N}$ & $\mathrm{Y}$ \\
\hline Observations & $1,792,506$ & $1,792,506$ & $1,792,506$ & $1,792,506$ & 1792506 & $1,792,506$ & $1,792,506$ & $1,792,506$ \\
\hline$R^{2}$ & 0.21 & 0.258 & 0.28 & 0.283 & 0.51 & 0.475 & 0.478 & 0.513 \\
\hline Number of firms & 298,751 & 298,751 & 298,751 & 298,751 & 298751 & 298,751 & 298,751 & 298,751 \\
\hline Mean Dep. Var & 0.143 & 0.143 & 0.143 & 0.143 & 0.143 & 0.143 & 0.143 & 0.143 \\
\hline
\end{tabular}

Note: This table provides results for equations 4-2 and 4-3. The sample consists of firms that appear at least once in each database. The observation level is firm-bank type. Thee are two bank types: federal and private. The panel has three periods (2002-2006, 2007-2010, 2011-2014). The dependent variable is an indicator which equals one if a firm sign a credit contract with the bank in the period. I define a firm as politically connected if it contributes to candidates, committees and party directory in the federal level in the previous election. Government bank is a dummy for federal banks. The variable firm size is the log of the average number of employees in the period plus one. Robust standard errors clustered at the firm level reported in parentheses. ${ }^{* * *} \mathrm{p}<0.01,{ }^{* *} \mathrm{p}<0.05,{ }^{*} \mathrm{p}<0.1$. 
Table 5.2: Do Politically Connected firms receive more credit? (Intensive Margin)

\begin{tabular}{|c|c|c|c|c|c|c|c|c|}
\hline & $\begin{array}{c}(1) \\
\log (\operatorname{loan}+1)\end{array}$ & $\begin{array}{c}(2) \\
\log (\operatorname{loan}+1)\end{array}$ & $\begin{array}{c}(3) \\
\log (\operatorname{loan}+1)\end{array}$ & $\begin{array}{c}(4) \\
\log (\operatorname{loan}+1)\end{array}$ & $\begin{array}{c}(5) \\
\log (\operatorname{loan}+1)\end{array}$ & $\begin{array}{c}(6) \\
\log (\operatorname{loan}+1)\end{array}$ & $\begin{array}{c}(7) \\
\log (\operatorname{loan}+1)\end{array}$ & $\begin{array}{c}(8) \\
\log (\operatorname{loan}+1)\end{array}$ \\
\hline Politically Connected & $\begin{array}{r}-0.271^{* * *} \\
(0.0377)\end{array}$ & $\begin{array}{c}-0.552^{* * *} \\
(0.0384)\end{array}$ & $\begin{array}{c}-0.887^{* * *} \\
(0.0372)\end{array}$ & $\begin{array}{c}-0.950^{* * *} \\
(0.0377)\end{array}$ & & $\begin{array}{c}-0.494^{* * *} \\
(0.0410)\end{array}$ & $\begin{array}{c}-0.603^{* * *} \\
(0.0419)\end{array}$ & \\
\hline $\begin{array}{l}\text { Politically Connected } \\
{ }^{*} \text { Government Bank }\end{array}$ & $\begin{array}{c}0.700^{* * *} \\
(0.0459)\end{array}$ & $\begin{array}{c}0.700^{* * *} \\
(0.0459)\end{array}$ & $\begin{array}{c}0.700^{* * *} \\
(0.0459)\end{array}$ & $\begin{array}{c}0.827^{* * *} \\
(0.0464)\end{array}$ & $\begin{array}{c}0.700^{* * *} \\
(0.0593)\end{array}$ & $\begin{array}{c}-0.0844^{*} \\
(0.0477)\end{array}$ & $\begin{array}{c}0.132^{* * *} \\
(0.0487)\end{array}$ & $\begin{array}{c}0.827^{* * *} \\
(0.0598)\end{array}$ \\
\hline Firm Size & & & $\begin{array}{l}1.407^{* * *} \\
(0.00718)\end{array}$ & $\begin{array}{l}1.407^{* * *} \\
(0.00718)\end{array}$ & & $\begin{array}{l}1.407^{* * *} \\
(0.00802)\end{array}$ & $\begin{array}{l}1.407^{* * *} \\
(0.00802)\end{array}$ & \\
\hline Bank FE & Y & $\mathrm{Y}$ & Y & $\mathrm{N}$ & Y & $\mathrm{N}$ & $\mathrm{N}$ & $\mathrm{N}$ \\
\hline Time FE & $\mathrm{N}$ & $\mathrm{Y}$ & Y & $\mathrm{N}$ & $\mathrm{N}$ & $\mathrm{Y}$ & $\mathrm{N}$ & $\mathrm{N}$ \\
\hline Firm FE & $\mathrm{Y}$ & $\mathrm{Y}$ & Y & $\mathrm{Y}$ & $\mathrm{N}$ & $\mathrm{N}$ & $\mathrm{N}$ & $\mathrm{N}$ \\
\hline Bank-Time FE & $\mathrm{N}$ & $\mathrm{N}$ & $\mathrm{N}$ & Y & $\mathrm{N}$ & $\mathrm{N}$ & Y & $\mathrm{Y}$ \\
\hline Bank-Firm FE & $\mathrm{N}$ & $\mathrm{N}$ & $\mathrm{N}$ & $\mathrm{N}$ & $\mathrm{N}$ & $\mathrm{Y}$ & Y & $\mathrm{N}$ \\
\hline Firm-Time FE & $\mathrm{N}$ & $\mathrm{N}$ & $\mathrm{N}$ & $\mathrm{N}$ & Y & $\mathrm{N}$ & $\mathrm{N}$ & Y \\
\hline Observations & $1,792,506$ & $1,792,506$ & $1,792,506$ & $1,792,506$ & $1,792,506$ & $1,792,506$ & $1,792,506$ & $1,792,506$ \\
\hline$R^{2}$ & 0.233 & 0.283 & 0.306 & 0.309 & 0.527 & 0.5 & 0.503 & 0.53 \\
\hline Number of firms & 298,751 & 298,751 & 298,751 & 298,751 & 298,751 & 298,751 & 298,751 & 298,751 \\
\hline Mean Dep. Var & 1.735 & 1.735 & 1.735 & 1.735 & 1.735 & 1.735 & 1.735 & 1.735 \\
\hline
\end{tabular}

Note: This table provides results for equations 4-2 and 4-3. The sample consists of firms that appear at least once in each database. The observation level is firm-bank type. Thee are two bank types: federal and private. The panel has three periods (2002-2006, 2007-2010, 2011-2014). The dependent variable is the log of loan size plus one. I define a firm as politically connected if it contributes to candidates, committees and party directory in the federal level in the previous election. Government bank is a dummy for federal banks. The variable firm size is the log of the average number of employees in the period plus one. Robust standard errors clustered at the firm level reported in parentheses. ${ }^{* * *} \mathrm{p}<0.01,{ }^{* *} \mathrm{p}<0.05,{ }^{*} \mathrm{p}<0.1$. 
Table 5.3: Heterogeneity by Electoral Outcome

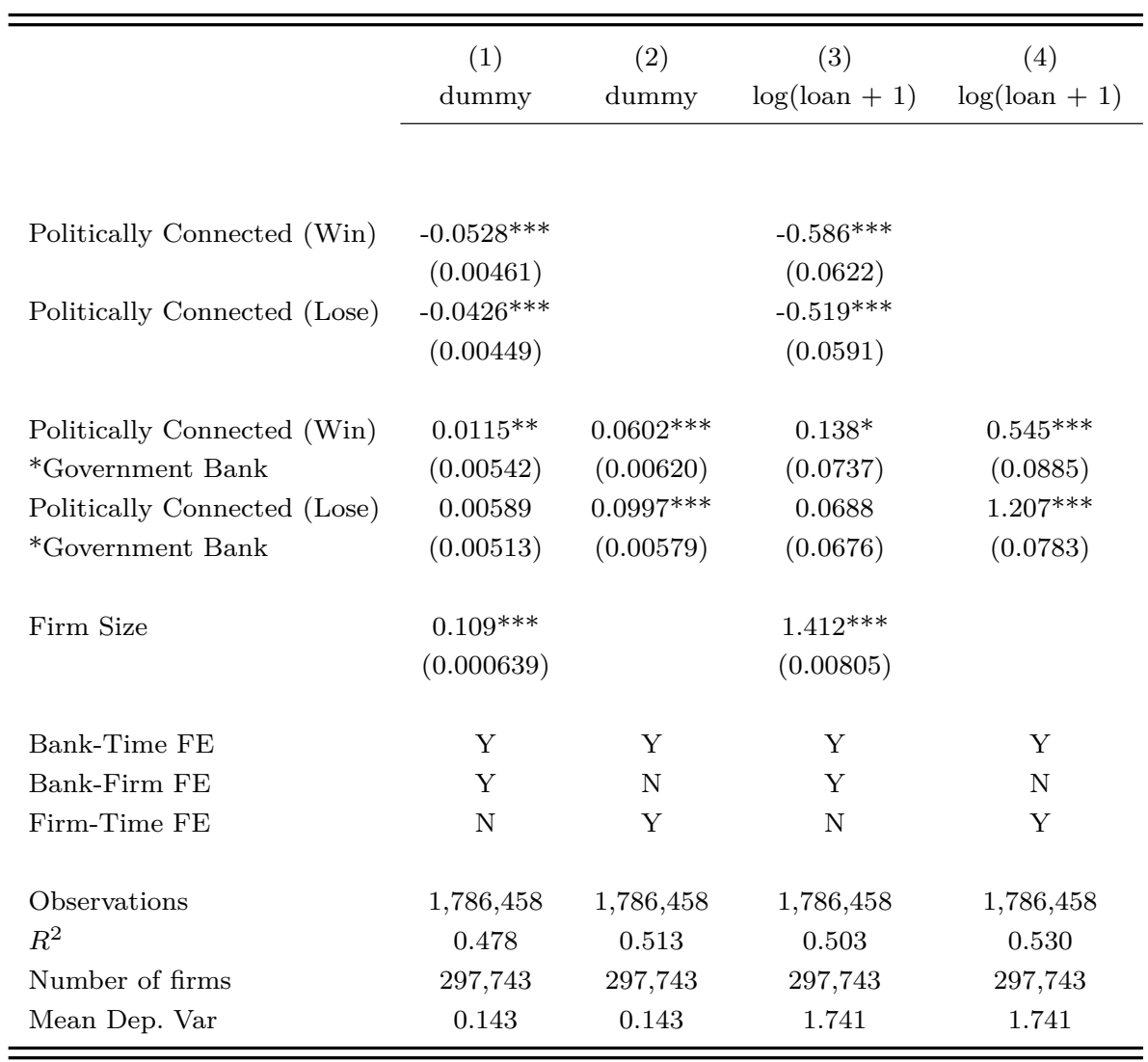

Note: The observation level is firm-bank type. Thee are two bank types: federal and private. The panel has three periods (2002-2006, 2007-2010, 2011-2014). The dependent variable is an indicator which equals one if a firm sign a credit contract with the bank in the period. I define a firm as politically connected ${ }^{*}$ win if it contributes to candidates who wins the election in the federal level in the previous election. I define a firm as politically connected * lose if it contributes to candidates who loses the election in the federal level in the previous election. Government bank is a dummy for federal banks. The variable firm size is the log of the average number of employees in the period plus one. Robust standard errors clustered at the firm level reported in parentheses. ${ }^{* *} \mathrm{p}<0.01,{ }^{* *} \mathrm{p}<0.05,{ }^{*} \mathrm{p}<0.1$. 
Table 5.4: Heterogeneity by Credit Line

\begin{tabular}{|c|c|c|c|c|}
\hline & $\begin{array}{c}(1) \\
\text { dummy }\end{array}$ & $\begin{array}{c}(2) \\
\text { dummy }\end{array}$ & $\begin{array}{c}(3) \\
\log (\operatorname{loan}+1)\end{array}$ & $\begin{array}{c}(4) \\
\log (\operatorname{loan}+1)\end{array}$ \\
\hline Politically Connected & $-0.0328^{* * *}$ & & $-0.368^{* * *}$ & \\
\hline *Finame & $(0.00319)$ & & $(0.0418)$ & \\
\hline Politically Connected & $-0.00928^{* * *}$ & & $-0.112^{* * *}$ & \\
\hline *Automatico & $(0.00131)$ & & $(0.0192)$ & \\
\hline Politically Connected & $-0.0101^{* * *}$ & & $-0.127^{* * *}$ & \\
\hline *Exim & $(0.000639)$ & & $(0.00951)$ & \\
\hline Politically Connected & $0.0207^{* * *}$ & $0.126^{* * *}$ & $0.245^{* * *}$ & $1.426^{* * *}$ \\
\hline *Government Bank*Finame & $(0.00357)$ & $(0.00411)$ & $(0.0469)$ & $(0.0567)$ \\
\hline Politically Connected & $-0.00923^{* * *}$ & $-0.0469^{* * *}$ & $-0.102^{* * *}$ & $-0.546^{* * *}$ \\
\hline *Government Bank*Automatico & $(0.00195)$ & $(0.00194)$ & $(0.0270)$ & $(0.0276)$ \\
\hline Politically Connected & -0.000634 & $-0.00191^{* * *}$ & -0.00977 & $-0.0314^{* * *}$ \\
\hline *Government Bank*Exim & $(0.000538)$ & $(0.000618)$ & $(0.00877)$ & $(0.0102)$ \\
\hline Firm Size & $\begin{array}{l}0.0362^{* * *} \\
(0.000212)\end{array}$ & & $\begin{array}{l}0.467 * * * \\
(0.00267)\end{array}$ & \\
\hline Bank-Time-Line FE & $\mathrm{Y}$ & $\mathrm{Y}$ & $\mathrm{Y}$ & $\mathrm{Y}$ \\
\hline Bank-Firm-Line FE & Y & $\mathrm{N}$ & Y & $\mathrm{N}$ \\
\hline Firm-Time FE & $\mathrm{N}$ & $\mathrm{Y}$ & $\mathrm{N}$ & $\mathrm{Y}$ \\
\hline Observations & $5,377,518$ & $5,377,518$ & $5,377,518$ & $5,377,518$ \\
\hline$R^{2}$ & 0.517 & 0.605 & 0.535 & 0.614 \\
\hline Number of firms & 298,751 & 298,751 & 298,751 & 298,751 \\
\hline Mean Dep. Var & 0.076 & 0.951 & 0.076 & 0.951 \\
\hline
\end{tabular}

Note: This table provides results for equation 5-1 and 5-2 . The sample consists of firms that appear at least once in each database. The observation level is firm-bank-line type. Thee are two bank types: federal and private. There ate three lines: Finame, Automático and Exim. The panel has three periods (2002-2006, 2007-2010, 2011-2014). In column (1), the dependent variable is the $\log$ of the loan size plus one. In column (2), the dependent variable is an indicator which equals one if a firm hires the line with the bank in the period. I define a firm as politically connected if it contributes to candidates, committees and party directory in the federal level in the previous election. Government bank is a dummy for federal banks. The variable firm size is the log of the average number of employees in the period plus one. Robust standard errors clustered at the firm level reported in parentheses. ${ }^{* * *} \mathrm{p}<0.01,{ }^{* *} \mathrm{p}<0.05,{ }^{*} \mathrm{p}<0.1$. 


\section{6 \\ Impact on Employment}

As described in previous section, the kind of credit studied in this paper is used to fund long-term investment. Particularly, one of its main goals is provide resources to firms that are constrained by credit. Thus, it is expected that after accessing these loans firms hire more workers. In this section, I test if obtaining a loan from BNDES fund has an impact on employment in the following years at the firm level. To assess this, I estimate the equation:

$$
\begin{array}{r}
\log (\text { Number of employees }+1)_{i, t+\tau}=\alpha_{i}+\alpha_{t}+\beta_{1} \text { Borrow from Government Bank } \text { Bat }_{i t} \\
+\beta_{2} \text { Borrow from Private } \text { Bank }_{i t}+\epsilon_{i t}
\end{array}
$$

where $\log (\text { Number of employees }+1)_{i, t+\tau}$ is the $\log$ of the number of employees plus one after $\tau$ years, Borrow from Government Bank ${ }_{i t}$ is a dummy that equals one if firm $i$ receive a credit from a government bank at time $t$, Borrow from Private $\mathrm{Bank}_{i t}$ is a dummy that equals one if firm $i$ receive a credit from a private bank at time $t, \alpha_{i}$ is firm fixed effect and $\alpha_{t}$ is time fixed effect.

Results are displayed in Table 6.1. Panel A gives estimates for impact on employment one year after receiving the credit. Panel B and $\mathrm{C}$ show results for two and three years after signing the loan contract respectively. In general, these results indicate that receiving a credit from BNDES fund has a positive and significant correlation with future levels of employment. This result is robust to controlling for state and economic sector trend. In Table 6.2, instead of a dummy, I use the log of the loan. Hence, the coefficient can be thought as the elasticity of the employment with respect to the loan size. According to the results, an increase of $1 \%$ in the amount of credit from private banks causes an expansion of $0.03 \%$ on employment in the following year, and the same increase from federal banks causes an expansion around $0.02 \$$

In both set of results, it is important to note that the impact is large for private credit. One interpretation for this is that private banks can choose better firms that are constrained by credit, causing a large impact on employment. This is consistent with La Porta et al. (2002) that argues that banks owned by government are less efficient. 
Table 6.1: Impact on Employment

\begin{tabular}{|c|c|c|c|c|}
\hline & $(1)$ & $(2)$ & (3) & $(4)$ \\
\hline \multicolumn{5}{|c|}{ Panel A: Log (number of employees +1$)_{t}$} \\
\hline \multirow[t]{2}{*}{ Borrow from Private Bank $_{t}$} & $0.425^{* * *}$ & $0.399^{* * *}$ & $0.425^{* * *}$ & $0.399^{* * *}$ \\
\hline & $(0.00207)$ & $(0.00212)$ & $(0.00207)$ & $(0.00212)$ \\
\hline \multirow[t]{2}{*}{ Borrow from Federal Bank $t$} & $0.250^{* * *}$ & $0.232^{* * *}$ & $0.253^{* * *}$ & $0.232^{* * *}$ \\
\hline & $(0.00230)$ & $(0.00235)$ & $(0.00232)$ & $(0.00236)$ \\
\hline Observations & $4,003,832$ & $3,671,108$ & $3,990,364$ & $3,671,108$ \\
\hline$R^{2}$ & 0.129 & 0.129 & 0.131 & 0.131 \\
\hline \multicolumn{5}{|c|}{ Panel B: Log (number of employees +1$)_{t+1}$} \\
\hline \multirow[t]{2}{*}{ Borrow from Private Bank $t$} & $0.349^{* * *}$ & $0.331^{* * *}$ & $0.349^{* * *}$ & $0.331^{* * *}$ \\
\hline & $(0.00197)$ & $(0.00201)$ & $(0.00197)$ & $(0.00201)$ \\
\hline \multirow[t]{2}{*}{ Borrow from Federal Bank $t$} & $0.192^{* * *}$ & $0.190^{* * *}$ & $0.192^{* * *}$ & $0.188^{* * *}$ \\
\hline & $(0.00226)$ & $(0.00230)$ & $(0.00228)$ & $(0.00231)$ \\
\hline Observations & $3,717,844$ & $3,408,886$ & $3,705,338$ & $3,408,886$ \\
\hline$R^{2}$ & 0.103 & 0.104 & 0.106 & 0.106 \\
\hline \multicolumn{5}{|c|}{ Panel C: Log (number of employees +1$)_{t+2}$} \\
\hline \multirow[t]{2}{*}{ Borrow from Private Bank $t$} & $0.264^{* * *}$ & $0.253^{* * *}$ & $0.264^{* * *}$ & $0.253^{* * *}$ \\
\hline & $(0.00190)$ & $(0.00194)$ & $(0.00190)$ & $(0.00194)$ \\
\hline \multirow[t]{2}{*}{ Borrow from Federal Bank $t$} & $0.131^{* * *}$ & $0.145^{* * *}$ & $0.130^{* * *}$ & $0.141^{* * *}$ \\
\hline & $(0.00232)$ & $(0.00235)$ & $(0.00234)$ & $(0.00236)$ \\
\hline Observations & $3,431,856$ & $3,146,664$ & $3,420,312$ & $3,146,664$ \\
\hline$R^{2}$ & 0.078 & 0.081 & 0.081 & 0.083 \\
\hline Year FE & $\mathrm{Y}$ & Y & Y & $\mathrm{Y}$ \\
\hline Firm FE & Y & Y & Y & $\mathrm{Y}$ \\
\hline Economic Sector Trend & $\mathrm{N}$ & $\mathrm{Y}$ & $\mathrm{N}$ & $\mathrm{Y}$ \\
\hline Regional Trend & $\mathrm{N}$ & $\mathrm{N}$ & $\mathrm{Y}$ & $\mathrm{Y}$ \\
\hline Number of firms & 285,988 & 262,222 & 285,026 & 262,222 \\
\hline
\end{tabular}

This table provides results for equation 6-1. The observation level is the firm. .The panel has 15 periods (2003-2017). In Panel A, the dependent variable is the $\log$ of the number of employees plus one in the following year. In Panel B and C, the dependent variable is the log of the number of employees plus one after two and three years. Robust standard errors clustered at the firm level reported in parentheses. ${ }^{* * *} \mathrm{p}<0.01,{ }^{* *} \mathrm{p}<0.05,{ }^{*} \mathrm{p}<0.1$ 
Table 6.2: Elasticity of Credit on Employment

\begin{tabular}{|c|c|c|c|c|}
\hline & $(1)$ & $(2)$ & (3) & (4) \\
\hline \multicolumn{5}{|c|}{ Panel A: Log (number of employees +1$)_{t}$} \\
\hline Log $(\text { Loan Private Bank })_{t}$ & $\begin{array}{l}0.0348^{* * *} \\
(0.000175)\end{array}$ & $\begin{array}{l}0.0327^{* * *} \\
(0.000179)\end{array}$ & $\begin{array}{l}0.0348^{* * *} \\
(0.000175)\end{array}$ & $\begin{array}{l}0.0327^{* * *} \\
(0.000179)\end{array}$ \\
\hline Log $(\text { Loan Federal Bank })_{t}$ & $\begin{array}{l}0.0208^{* * *} \\
(0.000175)\end{array}$ & $\begin{array}{l}0.0192^{* * *} \\
(0.000202)\end{array}$ & $\begin{array}{c}0.0209^{* * *} \\
(0.0002)\end{array}$ & $\begin{array}{c}0.0192^{* * *} \\
(0.000203)\end{array}$ \\
\hline Observations & 4003832 & 3671108 & 3990364 & 3671108 \\
\hline$R^{2}$ & 0.13 & 0.132 & 0.131 & 0.132 \\
\hline \multicolumn{5}{|c|}{ Panel B: Log (number of employees +1$)_{t+1}$} \\
\hline Log $(\text { Loan Private Bank })_{t}$ & $\begin{array}{l}0.0286^{* * *} \\
(0.000166)\end{array}$ & $\begin{array}{l}0.0271^{* * *} \\
(0.000169)\end{array}$ & $\begin{array}{l}0.0286^{* * *} \\
(0.000166)\end{array}$ & $\begin{array}{l}0.0271^{* * *} \\
(0.000169)\end{array}$ \\
\hline Log $(\text { Loan Federal Bank })_{t}$ & $\begin{array}{c}0.0161^{* * *} \\
(0.000194)\end{array}$ & $\begin{array}{l}0.0159^{* * *} \\
(0.000197)\end{array}$ & $\begin{array}{l}0.0161^{* * *} \\
(0.000195)\end{array}$ & $\begin{array}{c}0.0157^{* * *} \\
(0.000198)\end{array}$ \\
\hline Observations & 3717844 & 3408886 & 3705338 & 3408886 \\
\hline$R^{2}$ & 0.104 & 0.105 & 0.106 & 0.107 \\
\hline \multicolumn{5}{|c|}{ Panel C: Log (number of employees +1$)_{t+2}$} \\
\hline Log $(\text { Loan Private Bank })_{t}$ & $\begin{array}{c}0.0217^{* * *} \\
(0.00016)\end{array}$ & $\begin{array}{c}0.0206^{* * *} \\
(0.000163)\end{array}$ & $\begin{array}{l}0.0217^{* * *} \\
(0.000160)\end{array}$ & $\begin{array}{c}0.0206^{* * *} \\
(0.000163)\end{array}$ \\
\hline Log $(\text { Loan Federal Bank })_{t}$ & $\begin{array}{c}0.0111^{* * *} \\
(0.0002)\end{array}$ & $\begin{array}{l}0.0122^{* * *} \\
(0.000202)\end{array}$ & $\begin{array}{l}0.0110^{* * *} \\
(0.000201)\end{array}$ & $\begin{array}{c}0.0119 * * * \\
(0.000202)\end{array}$ \\
\hline Observations & 3431856 & 3146664 & 3420312 & 3146664 \\
\hline$R^{2}$ & 0.079 & 0.081 & 0.081 & 0.083 \\
\hline Year FE & $\mathrm{Y}$ & $\mathrm{Y}$ & $\mathrm{Y}$ & $\mathrm{Y}$ \\
\hline Firm FE & $\mathrm{Y}$ & $\mathrm{Y}$ & Y & $\mathrm{Y}$ \\
\hline Economic Sector Trend & $\mathrm{N}$ & $\mathrm{Y}$ & $\mathrm{N}$ & $\mathrm{Y}$ \\
\hline Regional Trend & $\mathrm{N}$ & $\mathrm{N}$ & $\mathrm{Y}$ & $\mathrm{Y}$ \\
\hline Number of firms & 285988 & 262222 & 285026 & 262222 \\
\hline
\end{tabular}

This table provides results for equation 6-1. The observation level is the firm. The panel has 15 periods (2003-2017). In Panel A, the dependent variable is the log of the number of employees plus one in the following year. In Panel B and C, the dependent variable is the log of the number of employees plus one after two and three years. Robust standard errors clustered at the firm level reported in parentheses. ${ }^{* * *} \mathrm{p}<$ $0.01,{ }^{* *} \mathrm{p}<0.05,{ }^{*} \mathrm{p}<0.1$ 


\section{Conclusion}

This paper investigates whether firms that contribute to elections receive more credit from state-owned banks. I address this question within the context of providing credit from the Brazilian development bank. I explore the variation of the same firm contributing and not contributing to political campaign at the federal level to identify the effect. Since these loans are operated by several commercial banks, I also explore variation of the type of bank. My identification strategy relies on bank-time, firm-bank and firm-time fixed effects. In addition to that, I use different measurements of political connections to test if the effect varies according to the strength of the politician.

My main findings suggest that banks owned by the federal government concede preferential access to firms that contribute to political elections in both margins. In contrast to this, these firms borrow less from private banks. This indicates that it may have a substitution effect on the behaviour of these firms. Thus, once a firm establishes connections with a politician, it asks for more credit from public banks and less from private ones. This mechanism supports the findings of Khwaja and Mian (2005).

I find different heterogeneous effect on electoral outcomes for different specifications. If I condition the effect on unobserved heterogeneity of the firmbank relationship, I document that firms that contribute to winning politicians borrow amounts $13 \%$ larger from government banks vis-à-vis firms without any connection and I estimate a zero effect for connections with losing candidates. However, If I condition the effect to firm shocks, I find that the effect for ties with losing candidates is almost twice the impact for connections with winning candidates.

If the model that takes into account bank-firm fixed effect is correct, these results support that firms that contribute to political campaigns receive more credit through a political channel. However, if the causal effect is correctly estimated in the model that controls for firm shocks, there are some reasons that can explain these findings. First, politicians often switch parties and have relatives in opposing parties. Second, politics is a long-term career in Brazil. Thus, a politician who is out of the power may still have power to influence some decisions since they have ties with the ones in the government or they 
will probably achieve a position soon. Khwaja and Mian (2005) found the the effect is almost equal go to winning ans losing politicians. They support that entering into the "political network" has equal importance as the politician's relative position within this network. Finally, contribution under the table are common in Brazil. Firms usually contribute through the official way and the illegal one (Carazza (2018)). As a result, a firm identified as a losing one in my data may still be connected with a winning politician through other illicit donations.

My findings indicate that there is heterogeneous effect by credit line. The positive effect from government banks toward politically connected firms is concentrated on Finame Line. The main goal of this line is to fund machine and equipment. This line also serves a wide variety of firms and, in the period studied in this paper, has the highest number of contracts. This kind of credit operation may provide politicians with more possibilities to channel funds

I also study the impact of borrowing money from BNDES fund on employment by type of bank. I document that credit from both banks has a positive and persistent correlation with future levels of employment. In addition to this, I find a large effect for private banks. One interpretation for this is that private banks can choose better firms that are constrained by credit, causing a large impact on employment. This is consistent with La Porta et al. (2002), who argue that banks owned by government are less efficient.

These results shed light to the literature on why firms contribute to political campaigns. Some previous works do not find that companies profit directly from these activities (Ansolabehere et al. (2003), Fowler et al. (2019)). Although Gordon et al. (2007) find that executives whose compensation is sensitive to firm profitability are more likely to donate politically, to the best of my knowledge, no work has found evidence of an objective benefit that includes a substantial quantity of firms and all economic sectors ${ }^{1}$. Also, my results converge from those found by Khwaja and Mian (2005). Nevertheless, they do not address the issue of campaign contribution and they do not look at heterogeneous effect by credit line.

Although I find evidence of this benefit only on credit lines funded by BNDES, it is possible that federal commercial banks also behave with political goals in other activities. Since they have a significant role in Brazil's economy, it appears that these banks may be a source of misallocation. Furthermore, my results, together with Boas et al. (2014) and Arvate et al. (2013), imply that firms used to have strong incentives to build ties with politicians through

\footnotetext{
${ }^{1}$ Baltrunaite (2018) and Titl and Geys (2019) also provide evidence that contributing can be profitable. However, they uses only firms that participates on government procurement.
} 
campaign donations in Brazil before the ban of corporate contributions. 


\section{Bibliography}

Acemoglu, D., Hassan, T. A., and Tahoun, A. (2018). The power of the street: Evidence from egypt's arab spring. The Review of Financial Studies, 31(1):1-42.

Acemoglu, D., Johnson, S., Kermani, A., Kwak, J., and Mitton, T. (2016). The value of connections in turbulent times: Evidence from the united states. Journal of Financial Economics, 121(2):368-391.

Akcigit, U., Baslandze, S., and Lotti, F. (2018). Connecting to power: Political connections, innovation, and firm dynamics. Working paper.

Amore, M. D. and Bennedsen, M. (2013). The value of local political connections in a low-corruption environment. Journal of Financial Economics, 110(2):387402.

Ansolabehere, S., de Figueiredo, J. M., and Snyder, James M., J. (2003). Why is there so little money in u.s. politics? Journal of Economic Perspectives, 17(1):105-130.

Arvate, P. R., Barbosa, K., and Fuzitani, E. (2013). Campaign donation and government contracts in Brazilian states. Textos para discussão, FGV/EESP Escola de Economia de São Paulo, Getulio Vargas Foundation (Brazil).

Baltrunaite, A. (2018). Political contributions and public procurement: Evidence from lithuania. Journal of the European Economic Association. forthcoming.

Bertrand, M., Duflo, E., and Mullainathan, S. (2004). How much should we trust differences-in-differences estimates? The Quarterly Journal of Economics, 119(1):249-275.

Boas, T. C., Hidalgo, F. D., and Richardson, N. P. (2014). The spoils of victory: Campaign donations and government contracts in brazil. The Journal of Politics, 76(2):415-429.

Carazza, B. (2018). Dinheiro, eleições e poder: as engrenagens do sistema político brasileiro. Editora Schwarcz S.A.

Carvalho, D. (2014). The real effects of government-owned banks: Evidence from an emerging market. The Journal of Finance, 69(2):577-609. 
Cingano, F. and Pinotti, P. (2012). Politicians at work: The private returns and social cost of political connections. Journal of the European Economic Association, 11(2):433-465.

Claessens, S., Feijen, E., and Laeven, L. (2008). Political connections and preferential access to finance: The role of campaign contributions. Journal of financial economics, 88(3):554-580.

Coelho, D. and de Negri, J. A. (2011). Impacto do financiamento do bndes sobre produtividade das empresas: uma aplicação do efeito quantílico de tratamento. Anais do xxxviii encontro nacional de economia, ANPEC.

Cole, S. (2009). Fixing market failures or fixing elections? agricultural credit in india. American Economic Journal: Applied Economics, 1(1):219-50.

Dinc, I. S. (2005). Politicians and banks: Political influences on government-owned banks in emerging markets. Journal of Financial Economics, 77(2):453-479.

Faccio, M. (2006). Politically connected firms. American Economic Review, 96(1):369-386.

Ferguson, T. and Voth, H.-J. (2008). Betting on hitler-the value of political connections in nazi germany. The Quarterly Journal of Economics, 123(1):101137.

Fisman, R. (2001). Estimating the value of political connections. American Economic Review, 91(4):1095-1102.

Fowler, A., Garro, H., and Spenkuch, J. L. (2019). Quid pro quo? corporate returns to campaign contributions. The Journal of Politics. forthcoming.

Gordon, S. C., Hafer, C., and Landa, D. (2007). Consumption or investment? on motivations for political giving. The Journal of Politics, 69(4):1057-1072.

Hillman, A. L. (1982). Declining industries and political-support protectionist motives. The American Economic Review, 72(5):1180-1187.

Houston, J. F., Jiang, L., Lin, C., and Ma, Y. (2014). Political connections and the cost of bank loans. Journal of Accounting Research, 52(1):193-243.

Hsieh, C.-T. and Klenow, P. J. (2009). Misallocation and manufacturing tfp in china and india*. The Quarterly Journal of Economics, 124(4):1403-1448.

Jayachandran, S. (2006). The jeffords effect. The Journal of Law and Economics, 49(2):397-425. 
Kau, J., Keenan, D., and Rubin, P. (1982). A general equilibrium model of congressional voting. Quarterly Journal of Economics, 107.

Khwaja, A. I. and Mian, A. (2005). Do lenders favor politically connected firms? rent provision in an emerging financial market. The Quarterly Journal of Economics, 120(4):1371-1411.

La Porta, R., Lopez-de Silanes, F., and Shleifer, A. (2002). Government ownership of banks. The Journal of Finance, 57(1):265-301.

Lazzarini, S. G., Musacchio, A., Bandeira-De-Mello, R., and Marcon, R. (2015). What do state-owned development banks do? evidence from bndes, 2002-09. World Development, 66.

Leão, S., De Mello, J. M., and Ferraz, C. (2014). Political Alliances and Credit Favoritism. PhD thesis, PUC-Rio.

Li, H., Meng, L., Wang, Q., and Zhou, L.-A. (2008). Political connections, financing and firm performance: Evidence from chinese private firms. Journal of Development Economics, 87(2):283-299.

Moon, T. and Schoenherr, D. (2018). Political connections and resource allocation in private markets: A social network channel. Working paper.

Restuccia, D. and Rogerson, R. (2008). Policy distortions and aggregate productivity with heterogeneous plants. Review of Economic Dynamics, 11(4):707-720.

Samuels, D. (2003). Ambition, Federalism, and Legislative Politics in Brazil. New York: Cambridge University Press.

Sapienza, P. (2004). The effects of government ownership on bank lending. Journal of Financial Economics, 71:357-384.

Schoenherr, D. (2019). Political connections and allocative distortions. Journal of Finance, 74(2).

Shleifer, A. and Vishny, R. W. (1994). Politicians and firms. The Quarterly Journal of Economics, 109(4):995-1025.

Snyder, J. M. (1990). Campaign contributions as investments: the u.s. house of representatives, 1980-1986. Journal of Political Economy, 98(6).

Titl, V. and Geys, B. (2019). Political donations and the allocation of public procurement contracts. European Economic Review, 111:443-458. 
A

Appendix

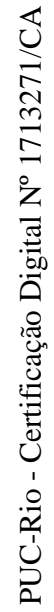




\section{A.1 \\ Values by Bank}

Table A.1: Amounts by Bank - 1

\begin{tabular}{|c|c|}
\hline Bank & Value (In $\mathrm{R} \$$ millions) \\
\hline ITAU UNIBANCO S.A. & $149,043.63$ \\
\hline BANCO DO BRASIL SA & $136,133.48$ \\
\hline BANCO BRADESCO S.A. & $129,210.79$ \\
\hline BANCO SANTANDER (BRASIL) S.A. & $57,439.50$ \\
\hline BANCO VOLKSWAGEN S.A. & $42,727.35$ \\
\hline BANCO MERCEDES-BENZ DO BRASIL S/A & $36,169.39$ \\
\hline BANCO VOTORANTIM S.A. & $30,004.99$ \\
\hline BANCO SAFRA S A & $28,277.23$ \\
\hline BANCO VOLVO (BRASIL) S.A & $16,551.51$ \\
\hline KIRTON BANK S.A. - BANCO MULTIPLO & $16,055.77$ \\
\hline CAIXA ECONOMICA FEDERAL & $14,064.33$ \\
\hline BANCO CATERPILLAR S.A. & $12,912.47$ \\
\hline BANCO J. SAFRA S.A & $12,248.47$ \\
\hline BANCO ABC BRASIL S.A. & $9,670.80$ \\
\hline BANCO ALFA DE INVESTIMENTO S.A. & $7,144.23$ \\
\hline BANCO CNH INDUSTRIAL CAPITAL S.A. & $4,797.62$ \\
\hline SCANIA BANCO S.A. & $4,425.20$ \\
\hline BANCO PINE S/A & $4,394.90$ \\
\hline BANCO ITAUBANK S/A & $3,928.61$ \\
\hline BANCO FIDIS S/A & $3,537.13$ \\
\hline BANCO CITIBANK S A & $3,260.85$ \\
\hline BANCO FIBRA S/A & $2,892.42$ \\
\hline BANCO MONEO S.A. & $2,756.69$ \\
\hline BANCO RODOBENS S.A. & $2,458.82$ \\
\hline BANCO DE LAGE LANDEN BRASIL S.A. & $1,805.04$ \\
\hline FINANCEIRA ALFA S.A. CREDITO, FINANCIAMENTO E INVESTIME & $1,537.53$ \\
\hline BANCO DAYCOVAL S/A & $1,241.53$ \\
\hline BANCO COOPERATIVO SICREDI S.A. & $1,184.82$ \\
\hline BANCO INDUSVAL SA & $1,106.75$ \\
\hline BANCO GUANABARA S/A & $1,032.26$ \\
\hline CHINA CONSTRUCTION BANK (BRASIL) BANCO MULTIPLO S/A & 916.46 \\
\hline BANCO BBM S/A & 771.79 \\
\hline BANCO BMG SA & 719.74 \\
\hline
\end{tabular}

Values are in $\mathrm{R} \$ 2017$ millions. 
Table A.2: Amounts by Bank - 2

\begin{tabular}{lr}
\hline \hline Bank & Value (In R\$ millions) \\
\hline BANCO MERCANTIL DO BRASIL SA & 628.02 \\
BANCO RANDON SA & 624.37 \\
BANCO BNP PARIBAS BRASIL S.A. & 545.30 \\
BANCO DA AMAZONIA SA & 537.64 \\
BANK OF AMERICA BRASIL LTDA. & 501.25 \\
BANK OF AMERICA BRASIL LTDA & 482.58 \\
BANCO INDUSTRIAL DO BRASIL S/A & 479.37 \\
BANCO DO NORDESTE DO BRASIL SA & 433.59 \\
BANCO RIBEIRAO PRETO S/A & 428.04 \\
MASSA FALIDA DO BANCO SANTOS & 426.98 \\
MASSA FALIDA DO BANCO BVA S.A. & 400.85 \\
BANCO MUFG BRASIL S.A. & 382.49 \\
BANCO BRADESCO FINANCIAMENTOS S/A & 344.88 \\
BANCO COOPERATIVO DO BRASIL S/A & 344.38 \\
BANCO RABOBANK INTERNATIONAL BRASIL S/A & 334.33 \\
BANCO RENDIMENTO S/A & 331.41 \\
BANCO SOFISA S.A. & 262.87 \\
BANCO MODAL S.A. & 254.21 \\
HAITONG BANCO DE INVESTIMENTO DO BRASIL S.A. & 247.33 \\
BANCO BPN BRASIL S/A & 235.05 \\
BANCO TRIANGULO S/A & 233.64 \\
BANCO SUMITOMO MITSUI BRASILEIRO S A & 222.52 \\
PARANA BANCO S/A & 208.18 \\
BANCO RURAL S.A - EM LIQUIDACAO EXTRAJUDICIAL & 156.68 \\
BANCO PROSPER S/A & 155.05 \\
BANCO JOHN DEERE S.A. & 152.16 \\
BANCO KDB DO BRASIL S/A & 134.82 \\
BANCO BONSUCESSO S/A & 130.73 \\
BANCO MIZUHO DO BRASIL S.A. & 116.28 \\
BANCO CAIXA GERAL - BRASIL S.A. & 74.99 \\
BANCO SOCIETE GENERALE BRASIL S.A. & 73.85 \\
BANCO J P MORGAN S/A & 72.40 \\
BANCO LUSO BRASILEIRO S/A & 62.54 \\
\hline \hline VAN & \\
\hline
\end{tabular}

Values are in $\mathrm{R} \$ 2017$ millions. 
Table A.3: Amounts by Bank - 3

\begin{tabular}{lr}
\hline \hline Bank & Value (In R \$ millions) \\
\hline BANCO ARBI S/A & 51.44 \\
BANCO UNICO S/A & 50.07 \\
DRESDNER BANK LATEINAMERIKA AKTIENGESELLSCHAFT & 47.74 \\
BRADESCO LEASING S.A. - ARRENDAMENTO MERCANTIL & 39.79 \\
BANCO INTERCAP S/A. & 34.04 \\
DIRECAO SA CREDITO FINANCIAMENTO E INVESTIMENTO & 32.29 \\
BRKB DISTRIBUIDORA DE TITULOS E VALORES MOBILIARIOS S.A & 32.08 \\
BANCO KEB HANA DO BRASIL S.A. & 26.06 \\
BANIF BANCO INTERNACIONAL DO FUNCHAL (BRASIL) S/A & 25.74 \\
BANCO PORTO REAL DE INVESTIMENTOS S/A & 23.32 \\
BCV BANCO DE CREDITO E VAREJO S/A & 20.62 \\
BANCO MORADA S/A - FALIDA & 20.39 \\
BANCO FINASA S/A & 15.85 \\
BANCO CETELEM S/A & 13.26 \\
BONCRED FINANCEIRA S/A CREDITO FINANC. E INVESTIMENTOS & 10.71 \\
BANCO BCN S/A. & 9.87 \\
SAFRA LEASING SA ARRENDAMENTO MERCANTIL & 9.00 \\
NOVO BANCO CONTINENTAL S.A.BANCO MULTIPLO & 7.79 \\
DEUTSCHE BANK SA BANCO ALEMAO & 5.73 \\
BANCO NEON S/A & 4.02 \\
BANCO GMAC S/A & 3.72 \\
BANCO PAULISTA SA & 1.06 \\
\hline \hline
\end{tabular}

Values are in $\mathrm{R} \$ 2017$ millions. 


\section{A. 2}

\section{Additional Descriptive Statistics}

Table A.4: Descriptive Statistics - Loan data

\begin{tabular}{lcccc}
\hline \hline & $\mathrm{N}$ & mean & median & sd \\
\cline { 2 - 5 } Finame loan (In R\$ 1,000) & & & & \\
Federal Banks & & & & \\
Connected Firms & 14,281 & 835.86 & 287.30 & $3,196.95$ \\
Not Connected Firms & 122,838 & 334.63 & 163.65 & $1,405.53$ \\
& & & & \\
Private Banks & & & & \\
Connected Firms & 75,606 & 717.16 & 265.50 & $3,599.72$ \\
Not Connected Firms & 721,125 & 311.37 & 168.00 & $1,866.79$ \\
& & & & \\
& & & & \\
Automático Loan (In R\$ 1,000) & & & & \\
Federal Banks & & & & \\
Connected Frms & 1,790 & $2,750.22$ & $1,000.00$ & $5,933.07$ \\
Not Connected Firms & 56,197 & 321.64 & 100.00 & $1,260.66$ \\
& & & & \\
Private Banks & & & & \\
Connected Frms & 3,481 & $4,378.27$ & $2,000.00$ & $6,530.44$ \\
Not Connected Firms & 14,220 & $1,859.36$ & 824.00 & $3,397.05$ \\
& & & & \\
& & & & \\
Exim Loan (In R\$ 1,000) & & & & \\
Federal Banks & & & & \\
Connected Firms & & & & \\
Not Connected Firms & 350 & $25,287.36$ & $9,852.20$ & $63,642.47$ \\
Private Banks & 614 & $26,699.68$ & $7,884.53$ & $44,863.80$ \\
Connected Firms & & & & \\
Not Connected Firms & & $18,814.33$ & $9,222.50$ & $32,057.43$ \\
\hline \hline & & $19,059.01$ & $6,172.43$ & $33,282.11$ \\
\hline
\end{tabular}


Table A.5: Descriptive Statistics - Number of employees by credit line

\begin{tabular}{lcccc}
\hline \hline & $\mathrm{N}$ & mean & median & sd \\
\cline { 2 - 5 } & & & & \\
Firms that borrow FINAME & $2,418,459$ & 42.58 & 5 & 413.81 \\
Firms that borrow AUTOMÁTICO & 541,800 & 64.76 & 7 & 521.03 \\
Firms that borrow EXIM & 8,674 & $1,287.43$ & 355 & $3,494.45$ \\
\hline \hline
\end{tabular}

Table A.6: Descriptive Statistics - Number of employees by kind of candidate

\begin{tabular}{lcccc}
\hline \hline & & & & \\
& $\mathrm{N}$ & mean & median & sd \\
\cline { 2 - 5 } & & & & \\
Connected with candidates for Presidency & 11,542 & $1,365.81$ & 162 & $4,746.97$ \\
Winner & 7,012 & $1,729.30$ & 288 & $5,674.50$ \\
Loser & 4,933 & $1,120.50$ & 60 & $4,213.56$ \\
& & & & \\
Connected with candidates for Upper House & 27,368 & 655.85 & 55 & $2,990.22$ \\
Winner & 17,074 & 848.09 & 86 & $3,492.07$ \\
Loser & 11,402 & 497.75 & 33 & $2,246.87$ \\
& & & & \\
Connected with candidates for Lower House & 173,476 & 235.11 & 14 & $1,562.51$ \\
Winner & 95,390 & 344.04 & 22 & $2,037.96$ \\
Loser & 84,154 & 138.38 & 10 & 679.43 \\
\hline \hline
\end{tabular}




\section{A.3}

Heterogeneous Effect by Electoral Outcome and Credit Line

Table A.7: Heterogeneity by Electoral Outcome and Credit Line

\begin{tabular}{|c|c|c|c|c|}
\hline & $\begin{array}{c}(1) \\
\text { dummy }\end{array}$ & $\begin{array}{c}(2) \\
\text { dummy }\end{array}$ & $\begin{array}{c}(3) \\
\log (\operatorname{loan}+1)\end{array}$ & $\begin{array}{c}(4) \\
\log (\operatorname{loan}+1)\end{array}$ \\
\hline Win*Finame & $\begin{array}{c}-0.0320^{* * *} \\
(0.00467)\end{array}$ & & $\begin{array}{c}-0.345^{* * *} \\
(0.0620)\end{array}$ & \\
\hline Win*Automatico & $\begin{array}{c}-0.00923^{* * *} \\
(0.00202)\end{array}$ & & $\begin{array}{c}-0.104^{* * *} \\
(0.0301)\end{array}$ & \\
\hline Win*Exim & $\begin{array}{l}-0.0115^{* * *} \\
(0.000964)\end{array}$ & & $\begin{array}{c}-0.144^{* * *} \\
(0.0144)\end{array}$ & \\
\hline Lose*Finame & $\begin{array}{c}-0.0209^{* * *} \\
(0.00457)\end{array}$ & & $\begin{array}{c}-0.244^{* * *} \\
(0.0592)\end{array}$ & \\
\hline Lose*Automatico & $\begin{array}{c}-0.0116^{* * *} \\
(0.00184)\end{array}$ & & $\begin{array}{c}-0.149 * * * \\
(0.0265)\end{array}$ & \\
\hline Lose*Exim & $\begin{array}{l}-0.0100^{* * *} \\
(0.000952)\end{array}$ & & $\begin{array}{c}-0.127^{* * *} \\
(0.0144)\end{array}$ & \\
\hline $\begin{array}{l}\text { Win*Finame } \\
{ }^{*} \text { Government Bank } \\
\text { Win*Automatico } \\
\text { *Government Bank } \\
\text { Win*Exim } \\
\text { *Government Bank }\end{array}$ & $\begin{array}{c}0.0219^{* * *} \\
(0.00530) \\
-0.00914^{* * *} \\
(0.00294) \\
-0.00131 \\
(0.000862) \\
0.0100^{* *}\end{array}$ & $\begin{array}{c}0.110^{* * *} \\
(0.00598) \\
-0.0474^{* * *} \\
(0.00291) \\
-0.00280^{* * *} \\
(0.000986) \\
0.144^{* * *}\end{array}$ & $\begin{array}{c}0.260^{* * *} \\
(0.0707) \\
-0.100^{* *} \\
(0.0418) \\
-0.0224 \\
(0.0141) \\
0.114^{*}\end{array}$ & $\begin{array}{c}1.178^{* * *} \\
(0.0836) \\
-0.556^{* * *} \\
(0.0422) \\
-0.0474^{* * *} \\
(0.0166) \\
1.733^{* * *}\end{array}$ \\
\hline $\begin{array}{l}\text { Lose*Finame } \\
{ }^{*} \text { Government Bank } \\
\text { Lose*Automatico } \\
\text { *Government Bank } \\
\text { Lose*Exim } \\
\text { *Government Bank }\end{array}$ & $\begin{array}{c}(0.00505) \\
-0.00385 \\
(0.00270) \\
-0.000274 \\
(0.000792)\end{array}$ & $\begin{array}{c}(0.00564) \\
-0.0432 * * * \\
(0.00258) \\
-0.00129 * \\
(0.000782)\end{array}$ & $\begin{array}{c}(0.0656) \\
-0.0408 \\
(0.0369) \\
-0.00248 \\
(0.0126)\end{array}$ & $\begin{array}{c}(0.0754) \\
-0.497^{* * *} \\
(0.0354) \\
-0.0197 \\
(0.0120)\end{array}$ \\
\hline Firm Size & $\begin{array}{l}0.0363^{* * *} \\
(0.000213)\end{array}$ & & $\begin{array}{l}0.469 * * * \\
(0.00267)\end{array}$ & \\
\hline $\begin{array}{l}\text { Bank-Time-Line FE } \\
\text { Bank-Firm-Line FE } \\
\text { Firm-Time FE }\end{array}$ & $\begin{array}{l}\mathrm{Y} \\
\mathrm{Y} \\
\mathrm{N}\end{array}$ & $\begin{array}{l}\mathrm{Y} \\
\mathrm{N} \\
\mathrm{Y}\end{array}$ & $\begin{array}{l}\mathrm{Y} \\
\mathrm{Y} \\
\mathrm{N}\end{array}$ & $\begin{array}{l}\mathrm{Y} \\
\mathrm{N} \\
\mathrm{Y}\end{array}$ \\
\hline $\begin{array}{l}\text { Observations } \\
R^{2}\end{array}$ & $\begin{array}{c}5,359,374 \\
0.517\end{array}$ & $\begin{array}{c}5,359,374 \\
0.605\end{array}$ & $\begin{array}{c}5,359,374 \\
0.536\end{array}$ & $\begin{array}{c}5,359,374 \\
0.615\end{array}$ \\
\hline Number of firms & 297,743 & 297,743 & 297,743 & 297,743 \\
\hline Mean Dep. Var & 0.0768 & 0.9548 & 0.0768 & 0.9548 \\
\hline
\end{tabular}

The dependent variable is an indicator which equals one if a firm sign a credit contract with the bank in the period. The variable Firm Size is the log of the average number of employees in the period plus one. Robust standard errors clustered at the firm level reported in parentheses. 